\title{
Examining the Effects of the Destroying Ammunition, Mines and Explosive Devices on the Presence of Heavy Metals in Soil of Open Detonation Pit; Part 2: Determination of Heavy Metal Fractions
}

\author{
Neda Tešan Tomić • Slavko Smiljanić • M. Jović • \\ M. Gligorić • D. Povrenović • A. Došić \\ Received: 26 March 2018 / Accepted: 7 August 2018 / Published online: 24 August 2018 \\ (C) Springer Nature Switzerland AG 2018
}

\begin{abstract}
As a result of the destruction of ammunition, mines, and explosive devices by the method of open detonation, the increased concentration of heavy metals is often recorded in the soil of military polygons, which is a serious ecological problem. However, in order to determine the potential risk of such locations to the environment, it is necessary to determine, in addition to the total content, the forms in which the metals are present. In this paper, a sequential extraction method was used to analyze the six fractions of five heavy metals (cadmium, lead, nickel, copper, and zinc) in the soil of the polygon for destruction of ammunition, mines, and explosive devices. Samples were collected from the place of direct detonation (so-called pits) and from the edge of the pit. The aim of this research is
\end{abstract}

Electronic supplementary material The online version of this article (https://doi.org/10.1007/s11270-018-3950-7) contains supplementary material, which is available to authorized users.

N. Tešan Tomić $(\bowtie)$

Ministry of Defense of Bosnia and Herzegovina, Sarajevo, Bosnia and Herzegovina

e-mail: tesanneda@yahoo.com

S. Smiljanić · M. Gligorić · A. Došić

Faculty of Technology, University of East Sarajevo, Zvornik,

Bosnia and Herzegovina

M. Jović

Institute of Nuclear Science Vinča, University of Belgrade,

Belgrade, Serbia

D. Povrenović

Faculty of Technology and Metalurgy, University of Belgrade, Belgrade, Serbia determination of metal speciation in order to obtain a better insight in their mobility and risk arising from this. The results showed that heavy metals are predominantly present in the residual, oxide, and organic fractions. $\mathrm{Cd}$ and $\mathrm{Cu}$ were also significantly present in the mobile fractions due to conducted activities on the polygon. To assess the potential environmental risk of soil, the risk assessment code (RAC) and individual (ICF) and global (GCF) contamination factors were used. According to the RAC, the mobility and bioavailability of the analyzed heavy metals decreases in the following order: $\mathrm{Cd}>\mathrm{Cu}>\mathrm{Zn}>\mathrm{Pb}>\mathrm{Ni}$. ICF results show low to moderate risk, while GCF results show low risk in terms of heavy metal contamination in the examined area.

Keywords Open detonation · Heavy metals · Sequential extraction $\cdot$ Risk assessment

\section{Introduction}

The potential toxicity of heavy metals in soil or sediment is a function of their mobility and bioavailability, which depend on the phase of the metals and the chemical and physical processes that lead transformations between phases. One of the most critical properties of heavy metals that differentiates them from other toxic pollutants is that they are not biodegradable (Prasad 2008; Yang et al. 2012). Although several studies have determined the total metal contents of contaminated and non-contaminated soils, the total contents of heavy metals do not provide enough information to understand 
their various forms, mobility, bioavailability, or potential risks to the environment (Davutluoglu et al. 2011; Nemati et al. 2011a). In contrast, a metal speciation analysis of soil can provide a good indicator of the ecosystem quality. Accordingly, a number of sequential extraction procedures have been developed (Tessier et al. 1979; Ure et al. 1993; Rauret et al. 1999; Shiowatana et al. 2001; Smičiklas et al. 2015). In general, extraction procedures are widely used in determining soluble fractions in water, ion exchangeable, oxidereduced, and complexed and structurally bonded fractions (species) of metal (Gworek and Mocek 2003).

As a result of many industrial and military operations, a large area of soil becomes polluted with heavy metals. For example, after the interruption of combat operations, in the war-affected areas, the remnants of war stayed a long time in the form of various metal objects that represent a serious hazardous waste. Their residence time is dependent on soil redox properties, in particular the activities of protons $(\mathrm{pH})$ and electrons (pe). It also depends on the type of soil, the content of organic matter, the amount of precipitation, among other things. These materials progressively dissolve, and new minerals, mostly oxides, can form via precipitation from the supersaturated soil solution (Certini et al. 2013). Bullets, for instance, with the time, release some lead, which in soil has a complex chemical and mineralogical behavior that concludes with either plant uptake or precipitation of insoluble minerals (Manninen and Tanskanen 1993; Lin et al. 1995).

One of the most sensitive activities for the environment is the operation of destroying unstable ammunition, mines, and explosive devices by the method of open detonation. The open detonation procedure is carried out in very remote areas for safety reasons (Alverbro et al. 2009). Risks of open detonation are reflected in uncontrolled pollution of soil, air, and groundwater, risks of shock waves and fragments, and the emergence of unexploded ordnance (Best Practice Guide 2008; Mihelič 2012). Due to uncontrolled pollution, the open detonation of large ammunition stocks is banned in most of Western European countries (Best Practice Guide 2008).

Usually, the polygons for destroying unstable ammunition, mines, and explosive devices include a diameter of about $1 \mathrm{~km}$ from a smaller central space called a pit, where disposal and destruction of unstable ammunition take place. There might be several pits on the polygon, and their diameters are usually a few dozen meters. At the moment of detonation, the pollutants and fragments spread throughout the area. Moreover, at the site of the explosion, there is the physical degradation of the soil and "injection" of part of the pollutants into the surface layer of the soil. The greatest soil contamination occurs in the vicinity of the source, but aerosols are also transmitted at a greater distance by moving air masses. Heavy and large particles fall near the area of detonation, while small ones fly across the area with the help of the wind, posing a potential threat to the living world. Rain can affect the washing of heavy metals from the surface layer of soil to deeper layers (Hagfors 2013), which can significantly pollute the soil and possibly the surface and groundwater.

All the metals originally present in munitions are dispersed over polygons after the detonation, either in their original state or as other metallic compounds (Thiboutot et al. 2012). From the remnants of munitions, mines, and explosive devices, some metals are very often released into the soil, such as $\mathrm{Cr}, \mathrm{Sb}, \mathrm{As}, \mathrm{Cd}, \mathrm{Cu}$, $\mathrm{Hg}, \mathrm{Ni}$ and $\mathrm{Zn}$, and others (Certini et al. 2013).

Heavy metals produced during the explosion on military polygons can cause a number of adverse effects on the environment and human health (Greičiûté et al. 2007; Thiboutot et al. 2012; Thiboutot et al. 2013; Ampleman et al. 2013; Dias da Silva et al. 2014). Besides heavy metals, particles, nitrogen oxides, sulfur oxides, volatile organic compounds, and polycyclic aromatic hydrocarbons (PAHs) are also emitted during the explosion; they expose a serious health risk for people and ecosystems as well (SALW 2004).

The war in the former Yugoslavia contributed to the accumulation of weapons and associated ammunition. The Armed Forces of Bosnia and Herzegovina are responsible for resolving surpluses and destroying unstable ammunition, mines, and explosive devices. Representatives of the American company "Sterling International" provide logistical assistance in disposing of these surpluses on the field. Polygon for the destruction of ammunition, mines, and explosive devices "Glamoc" is located in the south-western part of Bosnia and Herzegovina in the area of the municipality of Glamoc. The nearest populated place is at the distance of approximately $2.5 \mathrm{~km}$ of the airline distance in the northwest direction. The polygon extends on the mild slopes of the central part of Glamocko Polje at an altitude of 1100 to $1150 \mathrm{~m}$ and covers the circular surface with a radius of $1100 \mathrm{~m}$ from the pit $\mathrm{F} 1$. The polygon is not enclosed by a fence. The terrain is 
typically a karst limestone permeable for atmospheric water, and there are no significant streams and watercourses (Dostava informacija za poligon Glamoč 2015). There are three pits on the polygon where open detonations are performed, marked with F1, F2, and F3. Pits are irregular, oval shaped, with a radius of 30 to $70 \mathrm{~m}$ and overlap each other, making an irregular shape (Fig. 3). The daily amount of explosives for destruction is $1000 \mathrm{~kg}$ net. The process of destroying ammunition, mines, and explosive devices with open detonation consists in delivering and matching of the defined amount of explosive devices to the pit area (Fig. 1), after which a controlled explosion is induced (Figs. 2 and 3).

According to data available from the Ministry of Defense of Bosnia and Herzegovina, in 2016, 322 tons of explosive devices were destroyed by open detonation at the polygon of Glamoc. It is estimated that after 2016, an additional 10.550, 20 tons of surplus of unstable ammunition, mines, and explosive devices should be destroyed in the future. Since its inception until the end of 2016, the Armed Forces of Bosnia and Herzegovina have destroyed 3.298 tons of unstable ammunition, mines, and explosive devices on the Glamoc polygon (Durres 2012).

This study addresses the impact of destroying the ammunition, mines, and explosive devices on the presence and mobility of heavy metals in soil pits. For this purpose, a number of composite soil samples were collected, which were then analyzed using sequential extraction for the presence of $\mathrm{Cd}, \mathrm{Pb}, \mathrm{Ni}, \mathrm{Cu}$, and $\mathrm{Zn}$. In addition to the fractions of the analyzed metals, pseudototal concentrations, $\mathrm{pH}$, and granulometric composition of the soil were determined (results are shown in the first part of the study).

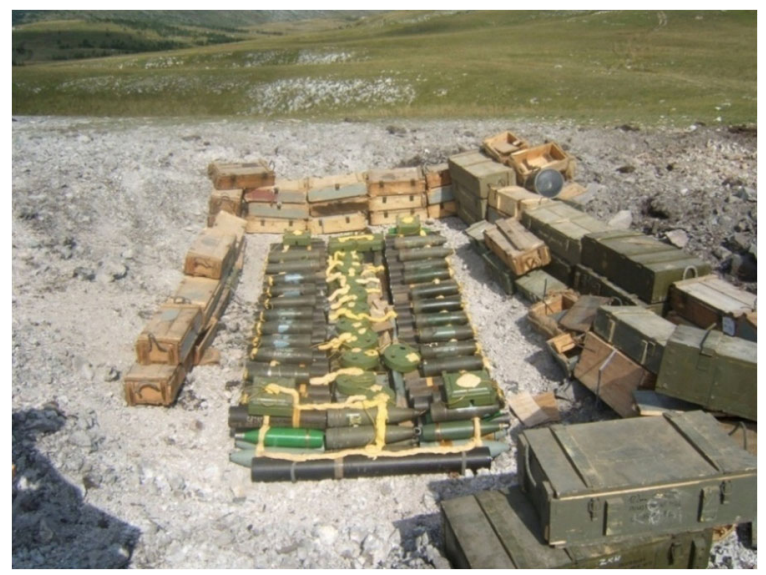

Fig. 1 Explosive devices in the pit, ready for destruction by open detonation

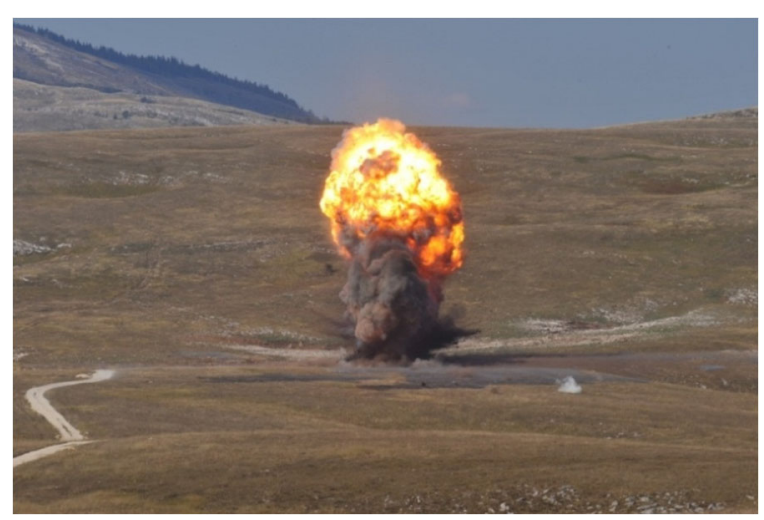

Fig. 2 Detonation at the pit

The aim of this research was to determine the forms in which the specific heavy metals were in the soil and their distribution with the depth of the soil in order to assess the impact and risks arising from the destruction of munitions, mines, and explosive devices at the site. Based on the results of the sequential extraction procedure, the calculation of the risk assessment code (RAC) and the individual (ICF) and global (GCF) contamination factors were used to estimate the degree of toxicity, i.e., the potential mobility and bioavailability of the analyzed metals, as well as their potential retention time in soil. Since the beginning of the polygon use, no similar tests have been performed. Obtaining reliable information on the concentrations and forms of metals on the subjected polygon is important for determining the degree of risk contamination at this site, as well as for determining the suitability for further exploitation of the polygon and undertaking technical measures to reduce the negative impact.

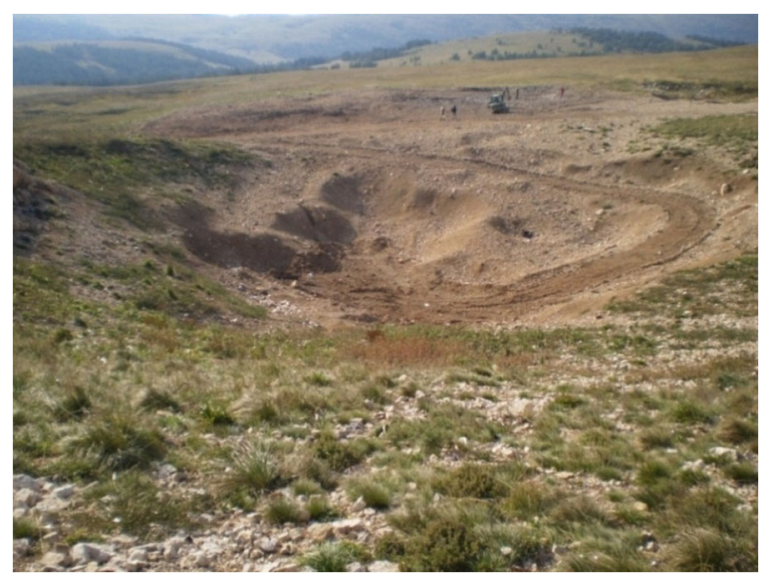

Fig. 3 View on pits F1 and F2 from pit F3, after an explosion 


\section{Materials and Methods}

\subsection{Soil Sampling}

For the purpose of study, 15 composite samples of the bodies were collected from pits and their edges. Soil sampling was carried out according to methods that are in accordance with BAS/EN/ISO standards (ISO 103811 2002; ISO 10381-2 2002). In order to consider metal distribution with depth, samples were collected in the surface (up to $30 \mathrm{~cm}$ ), sub-surface $(30-60 \mathrm{~cm}$ ), and deep soil $(60-100 \mathrm{~cm})$. For the purpose of sequential extraction, the following samples were considered: the center of the pits "F1," "F2," and "F3"; crater "K" formed on the pit F1 after detonations, and a sample collected in the north-east direction, $200 \mathrm{~m}$ from the center of the pit F1: "SI200." Figure 4 shows the locations at the polygon of Glamoc where the soil sampling was performed.

The composite sample $\mathrm{K}$ was formed by mixing two individual samples taken from the surface of $8 \times 10 \mathrm{~m}$, while the other composite samples were formed by mixing 9 individual samples taken from the surface of $20 \times 20 \mathrm{~m}$. Coordinates with altitudes are defined for each sampling place.

\subsection{Preparation of Soil Sample for Analysis}

Samples shipped to the laboratory were dried in a clean room at room temperature $\left(\approx 25^{\circ} \mathrm{C}\right)$ for $72 \mathrm{~h}$, spreading them onto a clean filter paper in a layer of 1 to $2 \mathrm{~cm}$ of thickness. After drying, different visible impurities were removed from the samples; the samples were grinded using a porcelain pestle and mortar, and then sieved through a sieve of $2 \mathrm{~mm}$. After that, the prepared samples were transferred to clean plastic boxes and stored for further laboratory testing.

\subsection{Determination of Metal Fractions}

In all the tested samples, the fractions of the following metals were determined: $\mathrm{Cd}, \mathrm{Pb}, \mathrm{Ni}, \mathrm{Cu}$, and $\mathrm{Zn}$. The basis for this was Tessier et al. method (Tessier et al. 1979),
Fig. 4 Soil sampling location at polygon of Glamoc. Samples: K denotes crater on the pit F1; F1, F2, and F3 denote pits; SI200 denotes sample collected in the north-east direction, $200 \mathrm{~m}$ from the center of the pit F1. Depths: (30) denotes 0 to $30 \mathrm{~cm},(60)$ denotes 30 to $60 \mathrm{~cm}$, and (100) denotes 60 to $100 \mathrm{~cm}$

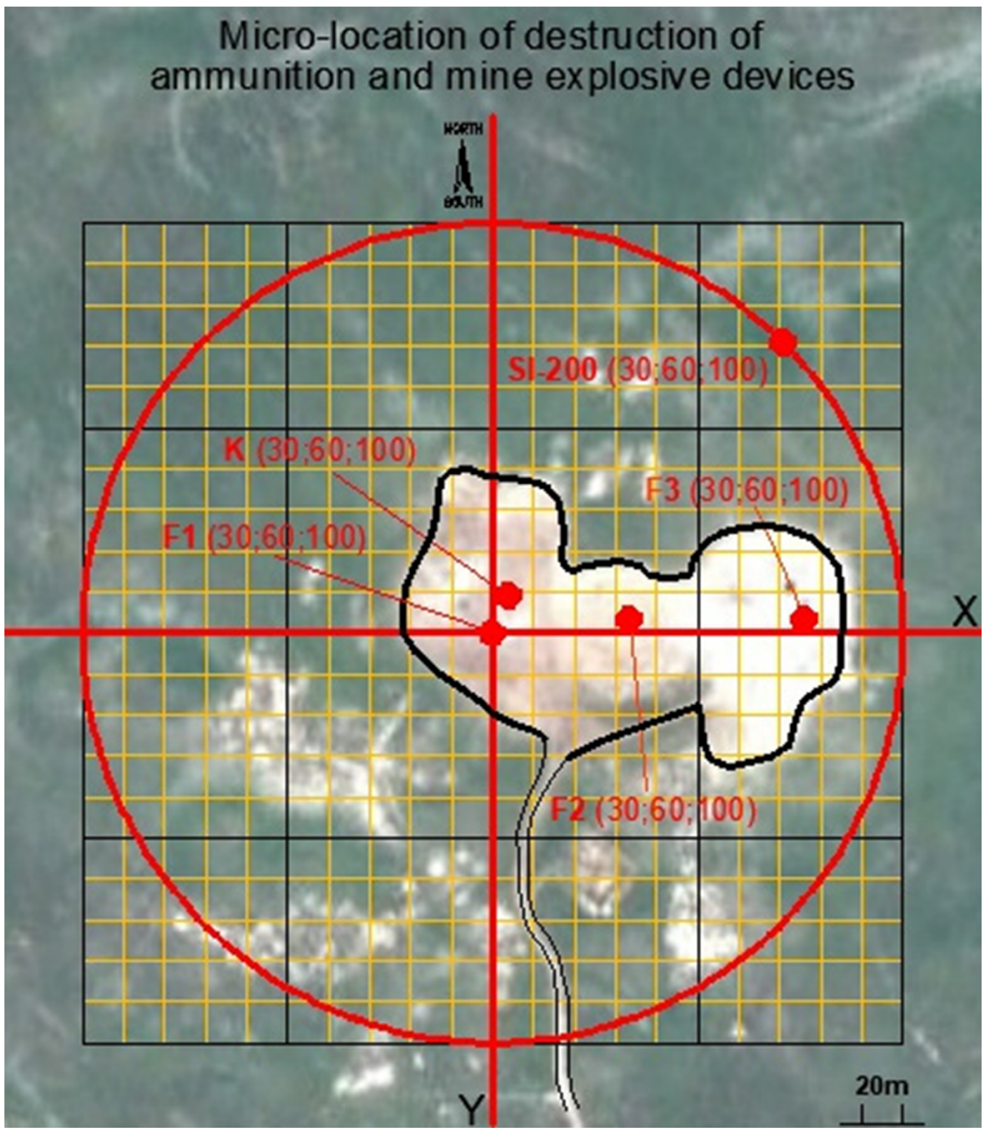


which was modified according to the Smičiklas et al. procedure (Smičiklas et al. 2015). The applied sequential extraction method consists of separating the treated metals into six fractions/phases: F0, water soluble; F1, exchangeable/sorptive; F2, specifically adsorbed/ carbonate; F3, iron-manganese oxide; F4, organic; and F5, residual/structurally bound in silicates. At the end of each interval, a liquid and solid phase is separated. Then, the concentration of the metal was determined in the extract, and the solid phase was again returned to the procedure by treatment with a stronger extraction agent.

To determine the metal concentration, a system of induced coupled plasma with optical emission spectrometry was used, the CAP 6500 Duo (Thermo Scientific, UK). All chemicals used were of the analytical purity manufactured by Merck.

\section{Results and Discussion}

Today, it is widely recognized that the distribution, mobility, and bioavailability of heavy metals and radionuclides in the environment do not only depend on their overall concentration, but also on the interactions of metal forms with solid-phase soil components to which they can be bound. Sorption of metals by plants depends on the chemical speciation and the relative distribution of the chemical forms of the metal in the soil solution. Some variations in chemical and physical conditions in the environment (atmospheric deposit, $\mathrm{pH}$, organic matter, soil texture, humic matter, and others) can cause the release of heavy metals into the environment that could result in contamination. This, in turn, will affect the availability and mobility of metals in the soil (Reddy et al. 1995). Toxicity, bioavailability, and mobility of heavy metals are related to their forms (Quevauviller et al. 1994; Malandrino et al. 2011). It is generally accepted that the environmental impacts of metals (e.g., their bioavailability, ecotoxicity, and the risk of contamination of groundwater) are more related to their mobile fractions than to their overall concentration (Cordos et al. 2003; Han et al. 2003). The sum of the mobile fractions can give a good insight into the mobility and bioavailability of the elements in the soil, and the greater the fraction, the larger the potential mobility and bioavailability. According to Zeien (1995), mobile fractions of heavy metals (which are accessible to plants) include water soluble metals (in the form of ions in soil solution), exchangeable fractions, and easily soluble metal-organic complexes. There are potentially bioavailable metal fractions which are included in the composition of organic compounds of low-stability and metals bound to carbonates. Residual fraction and fractions in which metals are bound to $\mathrm{Fe}$ and $\mathrm{Mn}$ oxides and organic matter are not accessible to plants because they have practically immobilized metals (Zeien 1995). Also, the sum of the concentrations of the analyzed element obtained in each step of the sequential extraction can be considered a pseudo-total content of that element in the soil (Marković et al. 2016). Chemical fractionation of metals and metalloids, in addition to estimating soil mobility, can serve as a useful tool for determining their origin, having in mind that the elements of anthropogenic source occur in earlier phases of sequential extraction, which are released by weaker extraction agents, while elements of lithogenic and pedogenous origin occur in stable soil fractions (de Passos et al. 2010; Canuto et al. 2013; Li et al. 2015).

Tables 1, 2, 3, 4, and 5 show the results of the fractionation of the analyzed heavy metals in the tested

Table 1 Concentrations of cadmium by fractions in the tested soil samples at different depths

\begin{tabular}{|c|c|c|c|c|c|c|c|}
\hline \multirow[t]{2}{*}{ Sample } & \multicolumn{7}{|c|}{ Concentration of $\mathrm{Cd}(\mathrm{mg} / \mathrm{kg})^{\mathrm{a}}$} \\
\hline & F0 & $\mathrm{F} 1$ & $\mathrm{~F} 2$ & $\mathrm{~F} 3$ & $\mathrm{~F} 4$ & F5 & $\Sigma$ \\
\hline SI200 (30) & $<\mathrm{DL}$ & 0.04 & 0.01 & 0.12 & 0.04 & 0.57 & 0.78 \\
\hline SI200 (60) & $<\mathrm{DL}$ & 0.02 & 0.00 & 0.08 & 0.02 & 0.49 & 0.61 \\
\hline SI200 (100) & $<\mathrm{DL}$ & 0.01 & 0.00 & 0.08 & 0.02 & 0.55 & 0.66 \\
\hline F1 (30) & 0.01 & 0.25 & 0.27 & 0.94 & 0.18 & 2.18 & 3.82 \\
\hline F1 (60) & $<\mathrm{DL}$ & 0.26 & 0.28 & 0.86 & 0.13 & 2.12 & 3.64 \\
\hline F1 (100) & $<\mathrm{DL}$ & 0.22 & 0.22 & 0.88 & 0.16 & 2.09 & 3.58 \\
\hline F2 (30) & $<\mathrm{DL}$ & 0.48 & 0.48 & 1.94 & 0.24 & 2.26 & 5.39 \\
\hline F2 (60) & $<\mathrm{DL}$ & 0.43 & 0.43 & 1.73 & 0.21 & 2.15 & 4.96 \\
\hline F2 (100) & $<\mathrm{DL}$ & 0.22 & 0.19 & 0.77 & 0.08 & 1.57 & 2.84 \\
\hline F3 (30) & $<\mathrm{DL}$ & 0.24 & 1.08 & 0.91 & 0.10 & 1.95 & 4.27 \\
\hline F3 (60) & $<\mathrm{DL}$ & 0.24 & 0.85 & 0.78 & 0.08 & 1.84 & 3.80 \\
\hline F3 (100) & $<\mathrm{DL}$ & 0.23 & 0.82 & 0.73 & 0.08 & 1.81 & 3.66 \\
\hline K (30) & $<\mathrm{DL}$ & 0.44 & 1.47 & 1.17 & 0.13 & 2.34 & 5.55 \\
\hline K (60) & $<\mathrm{DL}$ & 0.13 & 0.45 & 0.64 & 0.08 & 1.67 & 2.97 \\
\hline K (100) & $<\mathrm{DL}$ & 0.06 & 0.16 & 0.61 & 0.08 & 1.57 & 2.48 \\
\hline
\end{tabular}

Samples: K denotes the crater on the pit F1; F1, F2, and F3 denote pits; SI200 denotes sample collected in the north-east direction, $200 \mathrm{~m}$ from the center of the pit F1. Depths: (30) denotes 0 to $30 \mathrm{~cm}$, (60) denotes 30 to $60 \mathrm{~cm}$, and (100) denotes 60 to $100 \mathrm{~cm}$

${ }^{\mathrm{a}}$ The detection limit (DL) for $\mathrm{Cd}^{2+}$ ions was $0.0002 \mathrm{mg} / \mathrm{L}$ $(0.2 \mathrm{ppb})$; Values that exceed the maximum allowable concentration (M.A.C.) (Pravilnik FBiH 72/09) are in italic 
Table 2 Concentrations of lead by fractions in the tested soil samples at different depths

\begin{tabular}{|c|c|c|c|c|c|c|c|}
\hline \multirow[t]{2}{*}{ Sample } & \multicolumn{7}{|c|}{ Concentration of $\mathrm{Pb}(\mathrm{mg} / \mathrm{kg})^{\mathrm{a}}$} \\
\hline & F0 & $\mathrm{F} 1$ & $\mathrm{~F} 2$ & F3 & F4 & F5 & $\Sigma$ \\
\hline SI200 (30) & $<\mathrm{DL}$ & $<\mathrm{DL}$ & 0.12 & 3.00 & 2.96 & 23.80 & 29.88 \\
\hline SI200 (60) & $<\mathrm{DL}$ & $<\mathrm{DL}$ & 0.11 & 3.00 & 2.82 & 21.70 & 27.63 \\
\hline SI200 (100) & $<\mathrm{DL}$ & $<\mathrm{DL}$ & 0.14 & 4.60 & 2.84 & 23.30 & 30.88 \\
\hline F1 (30) & $<\mathrm{DL}$ & $<\mathrm{DL}$ & 0.35 & 11.00 & 2.46 & 43.00 & 56.81 \\
\hline F1 (60) & $<\mathrm{DL}$ & $<\mathrm{DL}$ & 0.45 & 12.40 & 1.70 & 39.40 & 53.95 \\
\hline F1 (100) & $<\mathrm{DL}$ & $<\mathrm{DL}$ & 0.32 & 10.40 & 3.80 & 40.40 & 54.92 \\
\hline F2 (30) & $<\mathrm{DL}$ & $<\mathrm{DL}$ & 0.60 & 11.20 & 4.80 & 27.30 & 43.90 \\
\hline F2 (60) & $<\mathrm{DL}$ & $<\mathrm{DL}$ & 0.80 & 12.80 & 5.44 & 28.70 & 47.74 \\
\hline F2 (100) & $<\mathrm{DL}$ & $<\mathrm{DL}$ & 1.02 & 13.20 & 4.20 & 25.60 & 44.02 \\
\hline F3 (30) & $<\mathrm{DL}$ & $<\mathrm{DL}$ & 1.05 & 11.20 & 1.22 & 29.40 & 42.87 \\
\hline F3 (60) & $<\mathrm{DL}$ & $<\mathrm{DL}$ & 1.04 & 12.00 & 1.30 & 28.20 & 42.54 \\
\hline F3 (100) & $<\mathrm{DL}$ & $<\mathrm{DL}$ & 1.28 & 12.60 & 1.56 & 27.80 & 43.24 \\
\hline K (30) & $<\mathrm{DL}$ & $<\mathrm{DL}$ & 1.20 & 13.00 & 0.90 & 41.80 & 56.90 \\
\hline K (60) & $<\mathrm{DL}$ & $<\mathrm{DL}$ & 0.80 & 12.40 & 1.74 & 32.90 & 47.84 \\
\hline K (100) & $<\mathrm{DL}$ & $<\mathrm{DL}$ & $<\mathrm{DL}$ & 8.60 & 2.12 & 28.20 & 38.92 \\
\hline
\end{tabular}

Samples: K denotes the crater on the pit F1; F1, F2, and F3 denote pits; SI200 denotes sample collected in the north-east direction, $200 \mathrm{~m}$ from the center of the pit F1. Depths: (30) denotes 0 to $30 \mathrm{~cm}$, (60) denotes 30 to $60 \mathrm{~cm}$, and (100) denotes 60 to $100 \mathrm{~cm}$

${ }^{\mathrm{a}}$ The detection limit (DL) for $\mathrm{Pb}^{2+}$ ions was $0.01 \mathrm{mg} / \mathrm{L}(10 \mathrm{ppb})$

Table 3 Concentrations of nickel by fractions in the tested soil samples at different depths

\begin{tabular}{|c|c|c|c|c|c|c|c|}
\hline \multirow[t]{2}{*}{ Sample } & \multicolumn{7}{|c|}{ Concentration of $\mathrm{Ni}(\mathrm{mg} / \mathrm{kg})^{\mathrm{a}}$} \\
\hline & F0 & $\mathrm{F} 1$ & $\mathrm{~F} 2$ & $\mathrm{~F} 3$ & $\mathrm{~F} 4$ & F5 & $\Sigma$ \\
\hline SI200 (30) & $<\mathrm{DL}$ & 0.11 & $<\mathrm{DL}$ & 2.34 & 2.25 & 35.50 & 40.20 \\
\hline SI200 (60) & $<\mathrm{DL}$ & 0.07 & $<\mathrm{DL}$ & 2.16 & 1.60 & 40.00 & 43.83 \\
\hline SI200 (100) & $<\mathrm{DL}$ & $<\mathrm{DL}$ & $<\mathrm{DL}$ & 2.20 & 1.64 & 53.20 & 57.04 \\
\hline F1 (30) & $<\mathrm{DL}$ & $<\mathrm{DL}$ & $<\mathrm{DL}$ & 4.16 & 2.59 & 64.50 & 71.25 \\
\hline F1 (60) & $<\mathrm{DL}$ & $<\mathrm{DL}$ & $<\mathrm{DL}$ & 3.68 & 1.71 & 57.00 & 62.39 \\
\hline F1 (100) & $<\mathrm{DL}$ & $<\mathrm{DL}$ & $<\mathrm{DL}$ & 4.86 & 2.84 & 84.60 & 92.30 \\
\hline F2 (30) & $<\mathrm{DL}$ & $<\mathrm{DL}$ & 0.09 & 4.68 & 2.39 & 48.60 & 55.76 \\
\hline F2 (60) & $<\mathrm{DL}$ & $<\mathrm{DL}$ & 0.09 & 4.86 & 2.48 & 47.70 & 55.13 \\
\hline F2 (100) & $<\mathrm{DL}$ & $<\mathrm{DL}$ & 0.08 & 3.96 & 1.96 & 54.20 & 60.20 \\
\hline F3 (30) & $<\mathrm{DL}$ & $<\mathrm{DL}$ & 0.31 & 6.24 & 1.66 & 49.30 & 57.51 \\
\hline F3 (60) & $<\mathrm{DL}$ & $<\mathrm{DL}$ & 0.30 & 3.96 & 1.24 & 55.80 & 61.30 \\
\hline F3 (100) & $<\mathrm{DL}$ & $<\mathrm{DL}$ & 0.32 & 3.96 & 1.28 & 55.70 & 61.26 \\
\hline K (30) & $<\mathrm{DL}$ & $<\mathrm{DL}$ & 0.24 & 3.68 & 1.30 & 71.10 & 76.32 \\
\hline K (60) & 0.12 & $<\mathrm{DL}$ & 0.20 & 4.68 & 1.64 & 73.10 & 79.74 \\
\hline K (100) & $<\mathrm{DL}$ & $<\mathrm{DL}$ & 0.17 & 6.23 & 2.23 & 75.30 & 83.93 \\
\hline
\end{tabular}

Samples: K denotes crater on the pit F1; F1, F2, F3 denote pits; SI200 denotes sample collected in the north-east direction, $200 \mathrm{~m}$ from the center of the pit F1. Depths: (30) denotes 0 to $30 \mathrm{~cm}$, (60) denotes 30 to $60 \mathrm{~cm}$, and (100) denotes 60 to $100 \mathrm{~cm}$

${ }^{\text {a }}$ The detection limit (DL) for $\mathrm{Ni}^{2+}$ ions was $0.01 \mathrm{mg} / \mathrm{L}(10 \mathrm{ppb})$; Values that exceed the maximum allowable concentration (M.A.C.) (Pravilnik FBiH 72/09) are in italic 
Table 4 Concentrations of copper by fractions in the tested soil samples at different depths

\begin{tabular}{|c|c|c|c|c|c|c|c|}
\hline \multirow[t]{2}{*}{ Sample } & \multicolumn{7}{|c|}{ Concentration of $\mathrm{Cu}(\mathrm{mg} / \mathrm{kg})^{*}$} \\
\hline & F0 & $\mathrm{F} 1$ & $\mathrm{~F} 2$ & $\mathrm{~F} 3$ & $\mathrm{~F} 4$ & F5 & $\Sigma$ \\
\hline SI200 (30) & 0.69 & $<\mathrm{DL}$ & $<\mathrm{DL}$ & 2.28 & 1.22 & 19.40 & 23.59 \\
\hline SI200 (60) & 0.67 & $<\mathrm{DL}$ & $<\mathrm{DL}$ & $<\mathrm{DL}$ & 1.34 & 19.40 & 21.41 \\
\hline SI200 (100) & 0.66 & $<\mathrm{DL}$ & $<\mathrm{DL}$ & $<\mathrm{DL}$ & 1.30 & 22.90 & 24.86 \\
\hline F1 (30) & 0.46 & 0.43 & 3.54 & 53.90 & 195.00 & 140.00 & 393.33 \\
\hline F1 (60) & 0.47 & 0.43 & 6.18 & 79.00 & 143.00 & 121.00 & 350.08 \\
\hline F1 (100) & 0.37 & 0.31 & 3.72 & 52.00 & 139.00 & 114.00 & 309.40 \\
\hline F2 (30) & 0.36 & 0.13 & 4.79 & 35.20 & 45.20 & 75.50 & 161.18 \\
\hline F2 (60) & 0.37 & 0.16 & 4.12 & 34.00 & 49.00 & 77.50 & 165.15 \\
\hline F2 (100) & 0.36 & $<\mathrm{DL}$ & 3.59 & 19.70 & 13.20 & 56.80 & 93.65 \\
\hline F3 (30) & 0.44 & 0.48 & 22.70 & 147.00 & 136.00 & 155.00 & 461.62 \\
\hline F3 (60) & 0.44 & 0.58 & 26.40 & 161.00 & 115.00 & 137.00 & 440.42 \\
\hline F3 (100) & 0.41 & 0.68 & 35.60 & 171.00 & 135.00 & 134.00 & 476.68 \\
\hline K (30) & 0.44 & 0.73 & 8.93 & 96.30 & 126.00 & 151.00 & 383.40 \\
\hline K (60) & 0.29 & 0.17 & 5.26 & 59.40 & 49.30 & 76.90 & 191.32 \\
\hline K (100) & 0.23 & $<\mathrm{DL}$ & 0.12 & 9.00 & 1.42 & 36.00 & 46.76 \\
\hline
\end{tabular}

Samples: K denotes crater on the pit F1; F1, F2, F3 denote pits; SI200 denotes sample collected in the north-east direction, $200 \mathrm{~m}$ from the center of the pit F1. Depths: (30) denotes 0 to $30 \mathrm{~cm}$, (60) denotes 30 to $60 \mathrm{~cm}$, and (100) denotes 60 to $100 \mathrm{~cm}$

${ }^{\mathrm{a}}$ The detection limit (DL) for $\mathrm{Cu}^{2+}$ ions was $0.01 \mathrm{mg} / \mathrm{L}(10 \mathrm{ppb})$; Values that exceed the maximum allowable concentration (M.A.C.) (Pravilnik FBiH 72/09) are in italic

soil samples, while Figs. 5, 6, 7, 8, and 9 show the distribution of the analyzed heavy metals (in \%) by fractions.

\subsection{Cadmium}

$\mathrm{Cd}$ is one of the most toxic and most mobile metals in the soil (Kubová et al. 2008), so its high proportion in mobile fractions potentially poses a risk for entering the food chain (Bogdanović 2002), which can, furthermore, have implications for the living world. Generally, larger part of $\mathrm{Cd}$ in mobile fractions of soil unambiguously indicates the existence and impact of anthropogenic pollution sources.

In all tested samples, $\mathrm{Cd}$ was most present in the residual phase (F5), where in the sample SI200, the proportion of $\mathrm{Cd}$ in the residual fraction (F5) was higher in relation to the samples from the pits and the crater (Fig. 5). In the SI200 sample, in which the only measured values of $\mathrm{Cd}$ were below the values for the maximum allowable concentration (M.A.C.) $(1.0 \mathrm{mg} / \mathrm{kg})$ (Pravilnik FBiH 72/09), the $\mathrm{Cd}$ distribution in phases was as follows: $\mathrm{F} 5>\mathrm{F} 3>\mathrm{F} 4 \approx \mathrm{F} 1>\mathrm{F} 2>\mathrm{F} 0$. The percentage of phases F4 and F1 decreased slightly with depth and was low (5.1-3 and 5.1-1.5\%, respectively). The part of Cd in the SI200 sample in fraction F3 was evenly distributed along the vertical soil profile (an average of $13.60 \%$ ), while the percentage of the F5 phase was the highest, and it increased with a sampling depth (from 73 to $83 \%$ ) (Fig. 5). A characteristic increase in the percentage of $\mathrm{Cd}$ in the residual fraction (F5) with depth was also recorded in the sample from the crater, where the percentage of $\mathrm{Cd}$ in the residual fraction (F5) increased from 42 to $63 \%$ (Fig. 5). This is expected since the percentage of clay on the polygon increased with depth, and most heavy metals have the ability of very intense binding to clay minerals (Belanović et al. 2003; Thiboutot et al. 2012). Cd present in clayey soil is not particularly dangerous, because it is mainly present in immobile fractions. Generally speaking, Cd shows more toxicity in sandy than in clayey soil (Vig et al. 2003). Clay, followed by the content of organic matter, is the dominant abiotic component in soil that reduces Cd toxicity (Doelman and Haanstra Doelman and Haanstra 1984). Complexation of Cd with organic matter and/or formation of insoluble chelates are a possible reason for its low bioavailability in clayey loamy soil and loamy soil (Lighthart et al. 
Table 5 Concentrations of zinc by fractions in the tested soil samples at different depths

\begin{tabular}{|c|c|c|c|c|c|c|c|}
\hline \multirow[t]{2}{*}{ Sample } & \multicolumn{7}{|c|}{ Concentration of $\mathrm{Zn}(\mathrm{mg} / \mathrm{kg})^{\mathrm{a}}$} \\
\hline & F0 & $\mathrm{F} 1$ & $\mathrm{~F} 2$ & $\mathrm{~F} 3$ & $\mathrm{~F} 4$ & F5 & $\Sigma$ \\
\hline SI200 (30) & 0.67 & 0.13 & 0.08 & 5.08 & 1.78 & 84.10 & 91.84 \\
\hline SI200 (60) & 0.37 & 0.10 & $<\mathrm{DL}$ & 2.86 & 1.30 & 88.80 & 93.43 \\
\hline SI200 (100) & 0.47 & 0.14 & 0.11 & 3.55 & 1.18 & 118.00 & 123.45 \\
\hline F1 (30) & $<\mathrm{DL}$ & $<\mathrm{DL}$ & 1.38 & 35.60 & 5.90 & 189.00 & 231.88 \\
\hline F1 (60) & $<\mathrm{DL}$ & $<\mathrm{DL}$ & 1.51 & 36.80 & 4.52 & 157.00 & 199.83 \\
\hline $1(100)$ & $<\mathrm{DL}$ & $<\mathrm{DL}$ & 1.94 & 49.20 & 8.96 & 201.00 & 261.10 \\
\hline F2 (30) & $<\mathrm{DL}$ & $<\mathrm{DL}$ & 1.46 & 26.60 & 5.26 & 108.00 & 141.32 \\
\hline F2 (60) & $<\mathrm{DL}$ & $<\mathrm{DL}$ & 1.46 & 29.00 & 5.66 & 107.00 & 143.12 \\
\hline $\mathrm{F} 2(100)$ & $<\mathrm{DL}$ & $<\mathrm{DL}$ & 2.30 & 20.60 & 3.48 & 109.00 & 135.38 \\
\hline F3 (30) & $<\mathrm{DL}$ & $<\mathrm{DL}$ & 6.58 & 37.20 & 3.20 & 140.00 & 186.98 \\
\hline F3 (60) & $<\mathrm{DL}$ & $<\mathrm{DL}$ & 4.76 & 32.60 & 3.14 & 127.00 & 167.50 \\
\hline F3 (100) & $<\mathrm{DL}$ & $<\mathrm{DL}$ & 5.17 & 32.00 & 3.40 & 126.00 & 166.57 \\
\hline K (30) & $<\mathrm{DL}$ & $<\mathrm{DL}$ & 5.38 & 35.20 & 3.02 & 198.00 & 241.60 \\
\hline K (60) & $<\mathrm{DL}$ & $<\mathrm{DL}$ & 2.78 & 20.80 & 2.24 & 138.00 & 163.82 \\
\hline K (100) & $<\mathrm{DL}$ & $<\mathrm{DL}$ & 0.68 & 7.14 & 0.92 & 131.00 & 139.74 \\
\hline
\end{tabular}

Samples: K denotes crater on the pit F1; F1, F2, F3 denote pits; SI200 denotes sample collected in the north-east direction, $200 \mathrm{~m}$ from the center of the pit F1. Depths: (30) denotes 0 to $30 \mathrm{~cm},(60)$ denotes 30 to $60 \mathrm{~cm}$, and (100) denotes 60 to $100 \mathrm{~cm}$

${ }^{\mathrm{a}}$ The detection limit (DL) for $\mathrm{Zn}^{2+}$ ions was $0.01 \mathrm{mg} / \mathrm{L}$ (10 ppb); Values that exceed the maximum allowable concentration (M.A.C.) (Pravilnik FBiH 72/09) are in italic

1983; Dar 1996). Various studies suggest that bioavailability of $\mathrm{Cd}$ in soil decreases with time, by increasing $\mathrm{pH}$, clay content, and organic matter in the soil. Christensen's (1984) research showed that the adsorption of $\mathrm{Cd}$ in sandy and loamy-clayey soil increases when the $\mathrm{pH}$ was increased from 4 to 7.7. These facts support the reduction of bioavailability of $\mathrm{Cd}$ at polygon of Glamoc, since the soil was alkaline and the clay content increased with increasing depth.

The sums of extracted $\mathrm{Cd}$ in the case of the remaining examined positions (F1, F2, F3, K) were significantly higher ( 2.5 to $5.55 \mathrm{mg} / \mathrm{kg}$ ) compared to the SI200 position, and showed a characteristic fall along the vertical profile (Table 1). Also, the observed decrease in the residual fraction (F5) was followed by an increase in the Fe/Mn oxide (F3) and carbonate fraction (F2) (Fig. 5). Since Cd cannot form stable organic complexes (Olajire et al. 2003), the association of $\mathrm{Cd}$ with organic matter is usually lower (Rule 1998), and hence the fact of very low concentrations of $\mathrm{Cd}$ in the organic phase. In the samples from the positions $\mathrm{F} 1, \mathrm{~F} 2, \mathrm{~F} 3$, and $\mathrm{K}$, the percentages of the most mobile fractions ranged from 12 to 15,14 to 18,29 to 31 , and 9 to 34\%, respectively, depending on the depth.

At the polygon of Glamoc, Cd appeared in the carbonate fraction (F2) in the area of the pits, while on the edge of the pit, the content of $\mathrm{Cd}$ in the carbonate fraction (F2) was negligible. The ionic cadmium, due to a similar ionic radius, can easily substitute $\mathrm{Ca}$ ions in calcite $\left(\mathrm{CaCO}_{3}\right)$ soil ( $\mathrm{Li}$ et al. 2015) and form a otavite $\left(\mathrm{CdCO}_{3}\right)$ that can occur in soil contaminated with cadmium (Nannoni et al. 2011), resulting in a high percentage of $\mathrm{Cd}$ in the carbonate-bonded fraction.

\subsection{Lead}

It is noticeable that none of the samples exhibited a $\mathrm{Pb}$ concentration above the M.A.C. $(80 \mathrm{mg} / \mathrm{kg})$ (Pravilnik $\mathrm{FBiH} 72 / 09) . \mathrm{Pb}$ is predominantly found in the residual phase (F5) (58-80\%) (Fig. 6). The sum of extracted $\mathrm{Pb}$ concentrations in the tested samples did not differ significantly along the vertical profile, except in the case of the $\mathrm{K}$ position where the concentration of $\mathrm{Pb}$ decreased from 57 to $39 \mathrm{mg} / \mathrm{kg}$ (Table 1). At the crater position, the highest and lowest concentrations of $\mathrm{Pb}$ are registered.

Distribution of $\mathrm{Pb}$ by fractions, in all the samples, was as follows: F5 $>$ F3 $>$ F4 $>$ F2 $>$ F1 $\approx$ F0. Similar observations can also be found for the distribution of lead in urban areas with anthropogenic impact. In studying $\mathrm{Pb}$ content at several different locations in urban areas, $\mathrm{Pb}$ was primarily related to the residual phase, while the least, it was represented in the exchangeable phase (Guo et al. 2005). Extremely high $\mathrm{Pb}$ concentrations in the residual fraction are explained by some authors by the presence of galenite $(\mathrm{PbS})$, which is the basic form of insoluble $\mathrm{Pb}$ in nature (Ogundiran and Osibanjo 2009). Results have also been published showing that the main geochemical sources of lead are Fe, Mn-oxide phase (mean 55.7\%), and residual phase (mean 30.2\%) (Sarkar et al. 2014). Marković et al. (2016) showed that in the uncontaminated soil with significantly different physico-chemical properties, from the territory of the Republic of Serbia, $\mathrm{Pb}$ is mainly related to the $\mathrm{Fe}, \mathrm{Mn}$-oxide fraction (32-66\%), and then to the organic $(17-45 \%)$ and residual fraction (13-27\%), while negligible concentrations of $\mathrm{Pb}$ were measured in the F0 and F1 phases.

In the analyzed samples, a slight decrease of $\mathrm{Pb}$ proportion in the residual fraction (F5) followed the increase of the $\mathrm{Pb}$ proportion in the Fe-Mn oxide phase (F3), wherein the $\mathrm{Pb}$ proportion in the Fe-Mn oxide 
Fig. 5 Distribution of Cd by soil fractions sampled at different depths. Samples: K denotes crater on the pit F1; F1, F2, and F3 denote pits; SI200 denotes sample collected in the north-east direction, $200 \mathrm{~m}$ from the center of the pit F1. Depths: (30) denotes 0 to $30 \mathrm{~cm},(60)$ denotes 30 to $60 \mathrm{~cm}$, and (100) denotes 60 to $100 \mathrm{~cm}$
Fig. 6 Distribution of $\mathrm{Pb}$ by soil fractions sampled at different depths. Samples: K denotes crater on the pit F1; F1, F2, and F3 denote pits; SI200 denotes sample collected in the north-east direction, $200 \mathrm{~m}$ from the center of the pit F1. Depths: (30) denotes 0 to $30 \mathrm{~cm},(60)$ denotes 30 to $60 \mathrm{~cm}$, and (100) denotes 60 to $100 \mathrm{~cm}$
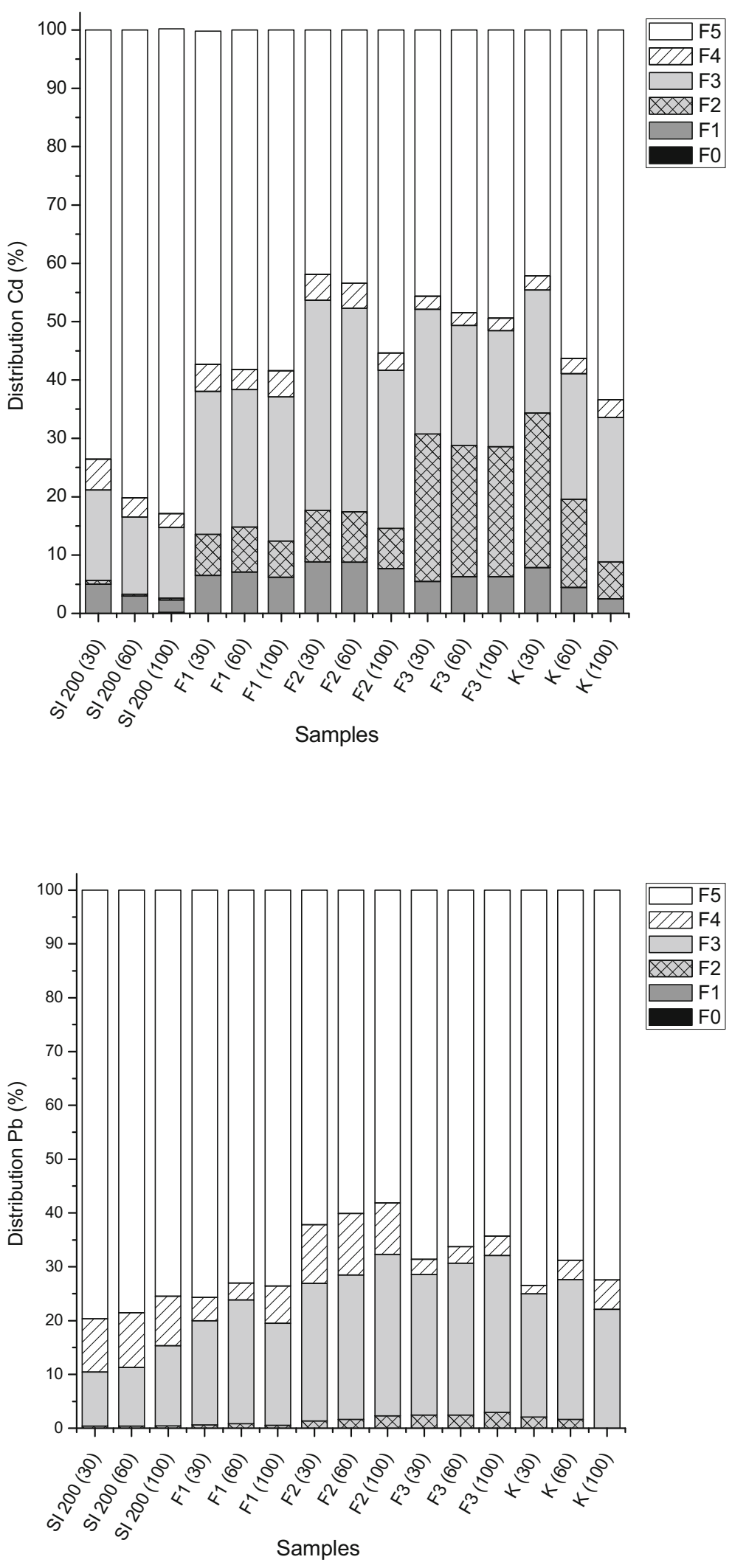
Fig. 7 Distribution of Ni by soil fractions sampled at different depths. Samples: K denotes crater on the pit F1; F1, F2, and F3 denote pits; SI200 denotes sample collected in the north-east direction, $200 \mathrm{~m}$ from the center of the pit F1. Depths: (30) denotes 0 to $30 \mathrm{~cm}$, (60) denotes 30 to $60 \mathrm{~cm}$, and (100) denotes 60 to $100 \mathrm{~cm}$

Fig. 8 Distribution of $\mathrm{Cu}$ by soil fractions sampled at different depths. Samples: K denotes crater on the pit F1; F1, F2, and F3 denote pits; SI200 denotes sample collected in the north-east direction, $200 \mathrm{~m}$ from the center of the pit F1. Depths: (30) denotes 0 to $30 \mathrm{~cm},(60)$ denotes 30 to $60 \mathrm{~cm}$, and (100) denotes 60 to $100 \mathrm{~cm}$
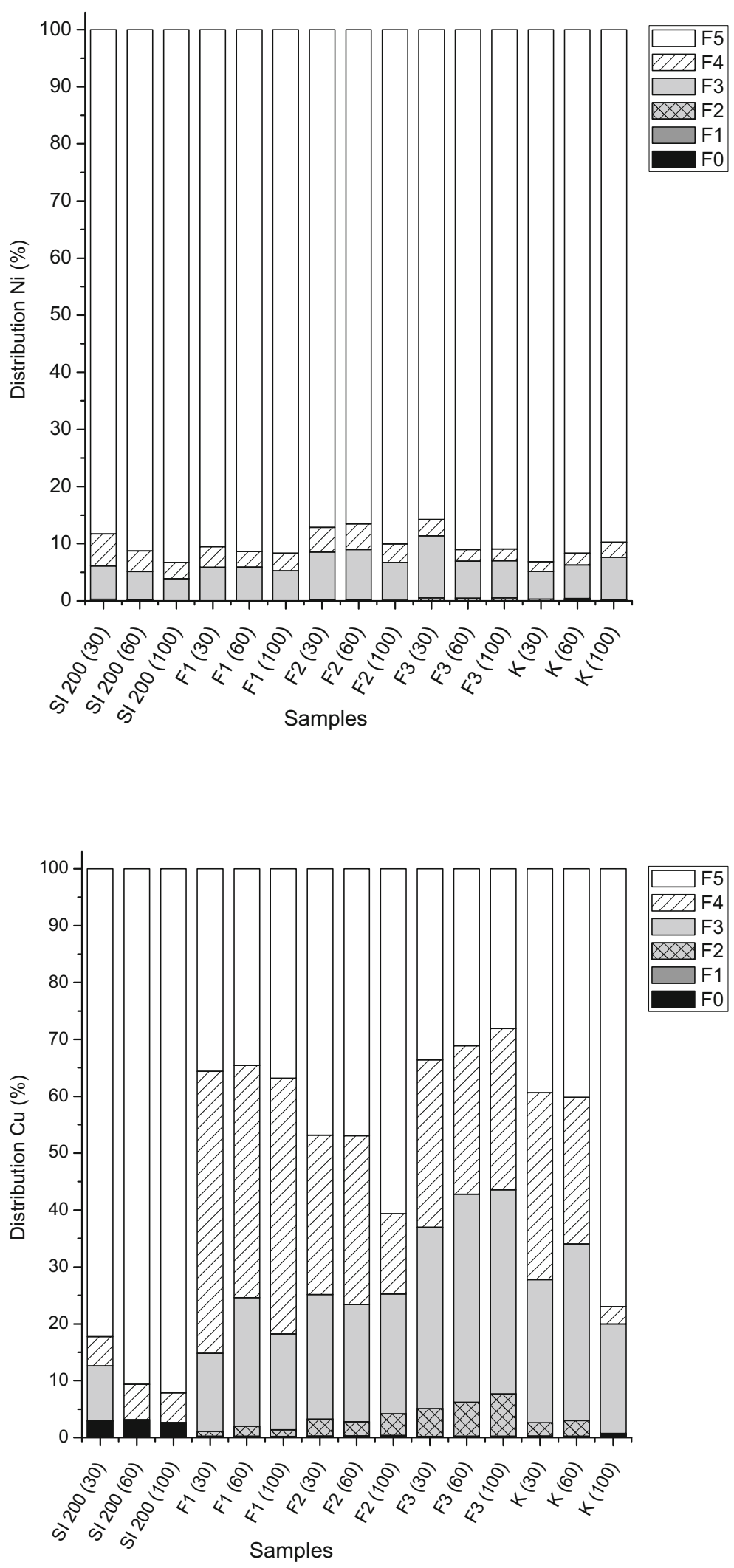
Fig. 9 Distribution of $\mathrm{Zn}$ by soil fractions sampled at different depths. Samples: K denotes crater on the pit F1; F1, F2, and F3 denote pits; SI200 denotes sample collected in the north-east direction, $200 \mathrm{~m}$ from the center of the pit F1. Depths: (30) denotes 0 to $30 \mathrm{~cm}$, (60) denotes 30 to $60 \mathrm{~cm}$, and (100) denotes 60 to $100 \mathrm{~cm}$

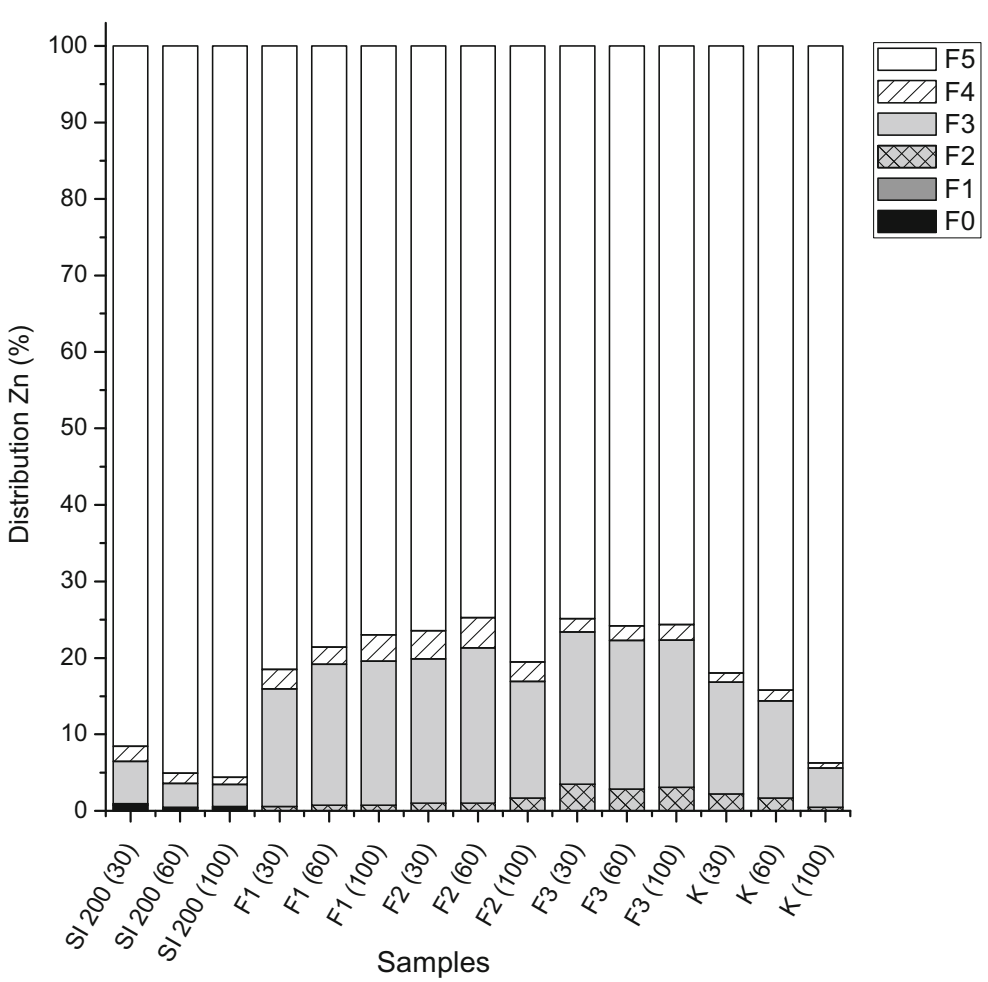

fraction (F3) was significantly higher in the area of the pits than on their edge (Fig. 6). This can be attributed to the destruction activities. Generally, the Fe/Mn oxide fraction of the soil represents excellent "collectors" of the metal in the soil, especially lead. The role of Fe-Mn oxide and hydroxide in lead retaining in soil has been proven in many cases; it was also confirmed in soil samples from industrial areas and military polygons (Dias da Silva et al. 2014; Barać 2017). Barać (2017) showed, based on BCR sequential extraction, that $\mathrm{Pb}$ in samples of contaminated agricultural soil is primarily related to $\mathrm{Fe}$ and $\mathrm{Mn}$ oxides/hydroxides (61\%). The high $\mathrm{Pb}$ affinity for $\mathrm{Fe} / \mathrm{Mn}$ oxides was also established on a military polygon in Brazil, which was used for destroying unstable munitions by an open detonation method, and it was noted that the total $\mathrm{Pb}$ concentration was higher in samples that were closer to the site of detonation and it was increasing with depth of sampling (Dias da Silva et al. 2014). Even, about $50 \% \mathrm{~Pb}$ was in the Fe-Mn oxide phase, and the remainder was mainly arranged in the following order: Residual fractions $>$ Complexed/Organic matter $>$ Soluble + Exchangeable + Carbonates. The highest total $\mathrm{Pb}$ concentration on this polygon was $178.66 \mathrm{mg} / \mathrm{kg}$ (Dias da Silva et al. 2014).
The high affinity of $\mathrm{Pb}$ to $\mathrm{Fe} / \mathrm{Mn}$ oxides was also confirmed by the Tessier method on soil samples from the industrial area. The results showed that $\mathrm{Pb}$ is most present in the oxide fraction (49\%), while it is below $1 \%$ in the bioavailable exchangeable fraction (Jena et al. 2013). Lead is able to form stable hydroxy and carbonate complexes that are preferentially bound to a slightly positively charged surface of Fe oxide (Hessling et al. 1989). The presence of soil organic matter also plays an important role in $\mathrm{Pb}$ adsorption. Soil organic matter may immobilize $\mathrm{Pb}$ via specific adsorption reactions, while mobilization of $\mathrm{Pb}$ can also be facilitated by its complexion with dissolved organic matter or fulvic acids (Bradl et al. 2005).

In all tested samples, the proportion of mobile phases was low. The presence of $\mathrm{Pb}$ in the water soluble (F0) and exchangeable (F1) fractions was not registered in any tested sample, while the $\mathrm{Pb}$ content in the carbonate phase (F2) was low (0-3\%). In the case of samples F1, $\mathrm{F} 2$, and F3, the fraction of the carbonate phase (F2) did not change significantly with depth, while in the case of sample K, the carbonate phase (F2) decreased with increasing depth and its presence was not registered in the depth sample (Table 1). Generally, the content of the carbonate fraction (F2) was lower on the edge of the pit 
than in the samples from the pits. At low $\mathrm{Pb}$ concentrations in the exchangeable fraction (F1), an important influence may have a soil $\mathrm{pH}$ that determines the bioavailability of $\mathrm{Pb}$. The low percentage of lead related to mobile phases is confirmed by the fact that the presence of lead at the examined site did not have a detrimental effect from these activities.

\subsection{Nickel}

Ni may be present at different locations in particles of soil. We find it as specifically adsorbed, adsorbed or enclosed in sesquioxides, fixed within a clay grid, or bound to organic residues and microorganisms when present in complex form with organic and inorganic ligands (Adriano 2001), which indicates the wide distribution of nickel in the soil.

In all tested samples, the sums of extracted Ni concentrations of sequential extraction were greater than the M.A.C. (40 mg/kg) (Pravilnik FBiH 72/09), which is consistent with the pseudo-total concentrations shown in the first part of the study. Sums of the extracted concentration of $\mathrm{Ni}$ in the case of examined positions grew along the vertical profiles (Table 3 ).

Proportion of fractions Ni followed the line: F5 $>>$ $\mathrm{F} 3>\mathrm{F} 4>\mathrm{F} 2 \approx \mathrm{F} 1 \approx \mathrm{F} 0$. In all examined samples, Ni was predominantly in the residual fraction (F5) (with over $85 \%$ ). Similar observations are found by other authors. Domination of Ni in residual phase was observed in different types of urban soil affected by various human activities (Guo et al. 2005; Sarkar et al. 2014). Kashem et al. (2007) showed that in contaminated soil, Ni was predominantly present in the residual fraction, and Ni concentration increased with the sampling depth in all the examined soil samples. In the same soil samples, a small percentage of the F3 fraction was reported, while the percentage of the F4 fraction ranged from 9 to 15\%. Ma and Rao (1997), using Tessier's method, tested nine soil samples from different contaminated sites within the US in which they found that $\mathrm{Ni}$ was predominantly located in the residual phase (in the range of 57-94\%), and it was not detected in any sample in the water soluble fraction.

Significant presence of $\mathrm{Ni}$ in the residual fraction can be associated with persistent mineralogy phases, such as residual silicate phases. Due to the high concentration of $\mathrm{Ni}$ in the samples, a dominant presence in the residual phase is a favorable circumstance for the environment. Generally, the metals present in the residual fraction are strongly bound to minerals and do not present any ecological risk (Wali et al. 2014).

According to the data, in sandy loamy soil, $\mathrm{Ni}$ is generally poorly mobile and appears in the residual fraction with more than $50 \%$ compared to the total concentration (Kabata-Pendias 2011). These observations are in line with our observations. This trend may be explained by residence time effect which may reduce metal mobility and bioavailability due to complexation, adsorption, and precipitation of metal ions in the soil particle surface (Zauyah et al. 2004). In addition, Lu et al. (2004) showed that time favorably influences the immobilization of $\mathrm{Ni}$ in the soil. They explored the time effect on the fractionation of heavy metals in soils and found that soluble metals were transformed from easily extractable fractions to more stable fractions.

It is also a favorable circumstance that, in most samples (except K60 and SI200 (30) and SI200 (60)), the Ni concentrations in the water soluble (F0) and exchangeable (F1) fractions were below the detection limit of the instrument, and the concentration of $\mathrm{Ni}$ in the carbonate phase (F2) was below the detection limit for samples SI200 and F1, while for other samples, it was very low $(0.08-0.32 \mathrm{mg} / \mathrm{kg})$. Presence of Ni in Fe-Mn oxide (F3) and organic (F4) fractions was also low and ranged from 2.1 to 6.2 and 1.2 to $2.8 \mathrm{mg} / \mathrm{kg}$, respectively.

The mobility of $\mathrm{Ni}$ in soil increases with decreasing $\mathrm{pH}$ and ion exchange capacity (Kastory Kastori 1997). Sanders and Adams (1987) showed that the addition of sludge and decreasing the soil $\mathrm{pH}(\mathrm{pH}<6)$ increased proportion of soluble Ni. As the soil on the polygon of Glamoc is alkaline, it can be characterized as beneficial from the aspect of immobilization of nickel. Relatively small amounts of $\mathrm{Ni}$ in mobile fractions show that the danger of this element to the environment is insignificant, since the most of $\mathrm{Ni}$ is bound to a stable and for the living world unreachable soil fractions.

\subsection{Copper}

The $\mathrm{Cu}$ concentrations in the water soluble (F0) and exchangeable (F1) fractions were generally low $(<$ $1 \mathrm{mg} / \mathrm{kg}$ ) (Table 4). For the most examined soil samples, the amounts of extracted $\mathrm{Cu}$ concentrations were greater than the M.A.C. (65 mg/kg) (Pravilnik FBiH 72/09).

The sum of the extracted $\mathrm{Cu}$ concentrations for the tested positions generally fell along the vertical soil profile, except for the SI200 position, where it was approximately the same value and position F3 where a 
certain decrease and than the increase in value was recorded. The extracted proportion of copper sample from the edge of the pit was noticeably smaller than the extracted concentrations from the pit samples, and the largest proportion of $\mathrm{Cu}$ was found in the residual fraction (F5) (over 80\%). With the increase in the sampling depth at the observed position, the increase in the fraction of $\mathrm{Cu}$ in phase $\mathrm{F} 5$ was followed by a decrease in the proportion of $\mathrm{Cu}$ in the $\mathrm{Fe}-\mathrm{Mn}$ oxide fraction (F3) (Sarkar et al. 2014). Metals that are related to the residual fraction are most likely incorporated in aluminumsilicate minerals (Wali et al. 2014).

In the case of the remaining positions, the proportion of $\mathrm{Cu}$ in certain fractions significantly was different from the soil sample on the edge of the pit. First of all, a significantly lower proportion of $\mathrm{Cu}$ was bound in the residual fraction (F5), while significantly higher $\mathrm{Cu}$ concentrations were related to fractions F4, F3, and F2. The proportion of copper in these fractions can be explained by the fact that these positions were exposed to the direct action of the explosion. The proportion of $\mathrm{Cu}$ in the carbonate fraction (F2) of the soil indicates the existence and impact of an anthropogenic source of pollution. The highest concentrations of $\mathrm{Cu}$ in the carbonate fraction (F2) were recorded in the sample from the pit F3, ranging from 4.92 to $7.50 \%$, along the vertical profile of the soil, which can be characterized as an unfavorable result. In the Dias da Silva et al. (2014) research that was carried out on the military polygon in Brazil, in the analyzed samples, $\mathrm{Cu}$ was dominantly bound in mobile fractions (soluble + exchangeable + carbonates) (total from 65.9 to $93.9 \%$ ), while the residue was assigned to the residual fraction, and this is why it was found to be a risk for the transfer of pollution. This is confirmed by the influence of the activities of destruction munitions, mines, and explosive devices on soil contamination by copper.

Variations in $\mathrm{Cu}$ concentrations in individual fractions in soil samples may depend on the source of pollution, the length of the destruction period, and the conditions of the soil. At positions F1 and K, the present quantities of $\mathrm{Cu}$ ranged on average in the residual fraction (F5) of 35 to $52 \%$, in the oxide fraction (F3) from 17 to $25 \%$, while in the organic phase (F4), 20 to $45 \%$ (Fig. 8). From this, it can be seen that the distribution of $\mathrm{Cu}$ in the soil is strongly influenced by organic matter and $\mathrm{Fe}$ and $\mathrm{Mn}$ oxides. A similar conclusion was made by Adriano (2001). The presence of $\mathrm{Cu}$ in the Fe-Mn oxide fraction can be explained by the fact that $\mathrm{Cu}^{2+}$ copper ions have an ionic radius similar to $\mathrm{Fe}^{3+}$ ions, so it could be incorporated into the crystal structure of Feoxide, while its bonding and presence in the organic phase F4 could be explained by affinity for complexing with organic substances, where it usually occurs in the form of soluble organic chelating agent (Kabata-Pendias 2011). The high affinity of $\mathrm{Cu}$ to oxides was also confirmed in the studies carried out by Cerqueira et al. (2011) and Vega et al. (2010). Of all transition metals, except $\mathrm{Pb}, \mathrm{Cu}$ is most strongly absorbed to $\mathrm{Fe}$ and $\mathrm{Al}$ oxides and oxyhydroxides (Adriano 2001). As the Fe and Mn minerals are naturally present in the soil, there is the greater presence of $\mathrm{Cu}$ in the $\mathrm{Fe} / \mathrm{Mn}$ oxide fraction in the area of the pit than on its edges, which indicates the anthropogenic sources in this fraction. Also, a higher proportion of copper in the organic fraction in the pit area than on its edge is due to the activity on the polygon. The increase in $\mathrm{pH}$ is beneficial for the immobilization of $\mathrm{Cu}$ by organic matter, primarily using humic and fulvic acid. With increasing $\mathrm{pH}, \mathrm{Cu}$ is more complexed with organic matter and thus becomes immobilized (Thomas 2015). Complexation with organic matter in the form of humic and fulvic acids is an effective mechanism for retaining $\mathrm{Cu}$ in the soil. It has been shown that $\mathrm{Cu}$, in comparison with other metals, is the most efficiently complexed with humic matter (Bradl et al. 2005). However, the copper bonded to the organic fraction is more phytoavailable than copper bound to the inorganic precipitate and the residual fraction. The bioavailability of the soluble forms of $\mathrm{Cu}$ depends probably the most on the molecular weight of the compound in which it is bound and the quantity in which it is present. Generally, in the soil solution, the copper is controlled by reaction with active groups on the surface of the solid phase and with the reactions with specific soil substances (Kabata-Pendias 2011).

\subsection{Zinc}

At certain positions, the measured $\mathrm{Zn}$ concentrations were greater than the M.A.C. (150 mg/kg) (Pravilnik $\mathrm{FBiH} 72 / 09)$. The extracted zinc is predominantly present in the residual fraction (F5), at 75\% and up (Fig. 9). Similar results can be found for urban and industrial areas (Kierczak et al. 2008).

More research has shown that soils with high content of clay and organic matter have a high zinc adsorption capacity and that zinc in the soil is dominantly adsorbed on clay minerals (Linsday 1972; Farrah and Pickering 1977; 
Kastori 1997). Alkaline conditions are favorable for the adsorption of $\mathrm{Zn}$ on minerals of clay and organic matter (Jurinak and Bauer 1956; Randhawa and Broadbent 1965).

Except in the residual fraction (F5), significant $\mathrm{Zn}$ concentrations in samples of pits and crater were also measured in the Fe-Mn oxide fraction (F3) (on average 10.8 to $19.5 \%$ ), while the proportion in the organic fraction (F4) was much smaller and negligible. This can be partly due to high stability constants of $\mathrm{Zn}$ oxide (Banerjee 2003), as well as the ability of Fe oxide to adsorb significant amounts of zinc and to cause $\mathrm{Zn}$ occlusion in the crystal lattice (Abdu 2010; Sarkar et al. 2014). Similar results can be found in studies of different contaminated soils. Thus, in samples of contaminated soil from the areas of different US locations, the percentage of zinc in the residual fraction was 55.8 to $97.6 \%$, while low concentrations were recorded in the water-soluble and organic fraction. In most examined samples, a significant presence of Fe/Mn oxide fraction (1.50-17.67\%) was also found (Ma and Rao 1997). The importance of Fe-Mn oxide in zinc accumulation has been confirmed during the scanning of the soil in the area of Derbyshire, England, polluted by industrial activities ( $\mathrm{Li}$ and Thornton 2001). On the other hand, in limestone and alkaline soils, the carbonate fraction may have a greater significance in zinc bonding, due to sorption of $\mathrm{Zn}$ with carbonate, by hydroxide and/or carbonate precipitation, or the formation of insoluble calcium zincate (Adriano 2001). The higher content of zinc in the mobile phase which leads to reducing the content of $\mathrm{Zn}$ in the residual phase is due to anthropogenic zinc intake. This was also confirmed during the testing the mobility of zinc in contaminated and uncontaminated soil in Japan (Kashem et al. 2011). On average, the proportion of $\mathrm{Zn}$ in contaminated soil in the residual, oxide, and mobile fractions were 42, 28, and $23 \%$ respectively, while the corresponding values in uncontaminated soils were 64,23 , and $4 \%$.

Organic matter is a significant factor that influences the behavior of $\mathrm{Zn}$ in the soil. Fulvic and organic acids with low molecular weight form soluble complexes and chelates with $\mathrm{Zn}$ and thus increasing the mobility of $\mathrm{Zn}$ (Shuman 1975).

The presence of $\mathrm{Zn}$ in the carbonate fraction (F2) at the polygon of Glamoc at the positions of the pits and crater could be a result of anthropogenic influence due to the destruction of the unstable munitions, but generally, these values were low (the highest percentage was found at position F3 and ranged from 3.5 to $3.1 \%$, depending on the depth). The connection of carbonate fraction with anthropogenic zinc intake was confirmed by Barać (2017) in samples of contaminated agricultural soil from industrial activities. He showed that $\mathrm{Zn}$ which has been the result of anthropogenic activities in soil, primarily associated with carbonate minerals.

In all samples of soil from the pits and crater, the concentrations of $\mathrm{Zn}$ in the water soluble (F0) and exchangeable (F1) were below the instrument detection limit, and in the SI (200), samples were negligible (below 1\%).

All of the above indicates that polygon of Glamoc, or the activities carried out within it, has a lesser impact on soil contamination from the aspect of $\mathrm{Zn}$ due to relatively small proportion in mobile and easily available fractions.

\subsection{Ecological Implications}

\subsubsection{Risk Assessment Code (RAC)}

The total metal concentration is often not sufficient to estimate the danger arising from them, because the different soils show a different degree of toxicity for the same total metal content, depending on which soil phase the metals are bound to. The distribution of metals in the soil may indicate a potential threat to the environment through the way in which the metals are connected. Evaluation of risk due to the bioavailability of heavy metals can be expressed by calculating the risk assessment code (RAC). Calculation of the risk assessment code is widely used in risk assessment of soil analysis (Guillén et al. 2012), sediment (de Passos et al. 2010; Zhu et al. 2012), etc. The essence of the procedure is in calculating the percentage of metals found in the exchangeable and carbonate fractions in relation to the total content (Table 6) (Jain 2004). Based on the value obtained, the risk assessment code or risk assessment is determined.

It is considered that soil less than to $1 \%$ exchangeable and carbonate fractions within the total metal content has no risk to the environment, while soil in which the exchangeable and carbonate fractions accounts more than $30 \%$ represents a high risk and over $50 \%$ reflects extreme risk for the environment and for the food chain (Nemati et al. 2011b; Ghrefat et al. 2012; Sungur et al. 2014).

The results of the sequential extraction showed that heavy metals $\mathrm{Cd}$ and $\mathrm{Zn}$ are predominantly present in the residual and oxide fractions, while $\mathrm{Pb}$ and $\mathrm{Ni}$ are 
Table 6 Risk assessment based on the percentage of metals in exchangeable and carbonate fractions in relation to the total concentration of metals in the soil

Criteria (\% Me in exchangeable and carbonate fractions)

\begin{tabular}{ll}
\hline No risk & $<1$ \\
Low risk & $1-10$ \\
Medium risk & $11-30$ \\
High risk & $31-50$ \\
Extreme risk & $>50$ \\
\hline
\end{tabular}

predominantly present in the residual fraction, then the oxide and organic fractions. $\mathrm{Cd}$ is also significantly presented in mobile fractions. $\mathrm{Cu}$ is distributed between the residual, oxide, and organic phases, depending on the samples, except for the position on the edge of the pit where the residual fraction is much more dominant. $\mathrm{Cu}$ is also significantly present in the carbonate fraction in the area of pits and crater (Figs. 1, 2, 3, 4, and 5).

Considering the mobile fractions in which the examined metals occurred, the differences between them were noticed. The mobility or the bioavailability of the analyzed heavy metals decreased in the following order: $\mathrm{Cd}>>\mathrm{Cu}>\mathrm{Zn}>\mathrm{Pb}>\mathrm{Ni}$. The percentage of mobile phases of $\mathrm{Cd}$ at the SI200 position ranged between 2 and $6 \%$, which is assessed as a low risk. In other examined samples, the proportions of $\mathrm{Cd}$ in mobile fractions were significantly higher. For samples from the positions F1 and $\mathrm{F} 2$, the proportion of mobile phases were in the range that corresponded to moderate risk (12-18\%). At F3 position, the risk was ranged from moderate to high (29-31\%), and at position $\mathrm{K}$, risk was ranged from low to high (9-34\%), depending on the depth of the sample. From the mobile fractions, $\mathrm{Pb}$ appeared only in the carbonate fraction. Taking into account the risk assessment guidelines, it could be concluded that the positions of SI200 and F1 do not pose an environmental risk for $\mathrm{Pb}$, since less than $1 \%$ of $\mathrm{Pb}$ is present in the carbonate fraction, while for other samples (F2, F3, and $\mathrm{K}$ ), there is low risk ( $\mathrm{Pb}$ content in the carbonate fraction is from 1 to $3 \%$ ). Ni did not pose a risk to the environment because in all tested samples, its content in mobile fractions was below $1 \%$. The proportion of mobile fractions of $\mathrm{Cu}$, in all examined positions, ranged from 1 to $8 \%$, which corresponds to the low-risk assessment code. In terms of Zn, the SI200 and F1 samples do not pose environmental risk, while the samples F2, F3, and $\mathrm{K}$ show low risk $(1-4 \%)$.
Based on the considered risk assessment code, it is concluded that the greatest danger to the living world comes from the $\mathrm{Cd}$, while other metals do not pose a threat to the environment of the examined area.

\subsubsection{Individual Contamination Factor (ICF) and Global Contamination Factor (GCF)}

In addition to RAC, it is important to explore the individual contamination factor (ICF) of heavy metals since it indicates the degree of risk of heavy metals to the environment in relation with their retention time (Moore et al. 2015). The ICFs were calculated for all analyzed samples from polygons as the ratio between the sum of the concentrations of metals extracted in the first five steps (water soluble, exchangeable, bound to carbonates, bound to iron and manganese oxides, and bound to organic matter) and concentrations found in residual forms (Jamali et al. 2007; Nemati et al. 2011a, b). According to Barona et al. (1999), the lower the ICF values, the higher the relative metal retention and lower risk of the environment. The global contamination factor (GCF) was calculated by summing the ICFs factor for each heavy metal obtained in the samples (Naji and Ismail 2011; Aiju et al. 2012). The individual contamination factor (ICF) and global contamination factor (GCF) classifications were interpreted as suggested by Zhao et al. (2012): ICF $<0$ and GCF $<6$ indicate low, 1 $<\mathrm{ICF}<3$ and $6<\mathrm{GCF}<12$ moderate, $3<\mathrm{ICF}<6$ and $12<\mathrm{GCF}<24$ considerable, and $\mathrm{ICF}>6$ and GCF $>24$ high contamination. The ICF and GCF values for the analyzed area are shown in Table 7.

In all samples, for all metals analyzed, the ICF values (except for surface samples F1 and K of Ni) and GCF were lower on the edge of the pit than in the area of pits and crater. The average ICF values for the heavy metals analyzed, regardless of depth, followed the same sequence: $\mathrm{Cu}>\mathrm{Cd}>\mathrm{Pb}>\mathrm{Zn}>\mathrm{Ni}$.

$\mathrm{Cd}$ and $\mathrm{Cu}$ had similar contamination factors in the surface and sub-surface layer, while in the deep layer, the factors of contamination had lower values. ICFs for $\mathrm{Cu}$ and $\mathrm{Cd}$ were significantly higher than for other metals. The highest ICF values for $\mathrm{Cu}$ were found in the deep sample of pit F3 and for $\mathrm{Cd}$ in the surface sample in the pit F2. These highest recorded values of ICF in soil samples for $\mathrm{Cu}$ and Cd (2.56 F3 (100) and 1.39 F2 (30), respectively) show just moderate contamination, but still low retention time and mobility potential (according to GCF). 
Table 7 Individual (ICF) and global (GCF) contamination factors in the tested soil samples

\begin{tabular}{|c|c|c|c|c|c|c|c|}
\hline \multirow[t]{2}{*}{ Depth } & \multirow[t]{2}{*}{ Sample } & \multicolumn{5}{|l|}{$\mathrm{ICF}^{\mathrm{a}}$} & \multirow[t]{2}{*}{$\mathrm{GCF}^{\mathrm{a}}$} \\
\hline & & $\mathrm{Cd}$ & $\mathrm{Pb}$ & $\mathrm{Ni}$ & $\mathrm{Cu}$ & $\mathrm{Zn}$ & \\
\hline \multirow{6}{*}{$0-30 \mathrm{~cm}$} & SI200 & 0.36 & 0.26 & 0.13 & 0.22 & 0.10 & 1.07 \\
\hline & $\mathrm{F} 1$ & 0.75 & 0.32 & 0.10 & 1.81 & 0.23 & 3.21 \\
\hline & $\mathrm{F} 2$ & 1.39 & 0.61 & 0.15 & 1.13 & 0.31 & 3.59 \\
\hline & F3 & 1.20 & 0.46 & 0.17 & 1.98 & 0.26 & 4.07 \\
\hline & K & 1.37 & 0.36 & 0.10 & 1.54 & 0.22 & 3.59 \\
\hline & Mean value & 1.01 & 0.40 & 0.13 & 1.37 & 0.22 & 3.53 \\
\hline \multirow{5}{*}{$30-60 \mathrm{~cm}$} & SI200 & 0.25 & 0.27 & 0.10 & 0.10 & 0.05 & 0.77 \\
\hline & $\mathrm{F} 1$ & 0.72 & 0.37 & 0.10 & 1.90 & 0.27 & 3.36 \\
\hline & $\mathrm{F} 2$ & 1.31 & 0.66 & 0.16 & 1.13 & 0.34 & 3.6 \\
\hline & F3 & 1.10 & 0.51 & 0.10 & 2.21 & 0.32 & 4.24 \\
\hline & $\mathrm{K}$ & 0.78 & 0.45 & 0.10 & 1.49 & 0.19 & 3.01 \\
\hline \multirow{7}{*}{$60-100 \mathrm{~cm}$} & Mean value & 0.83 & 0.45 & 0.11 & 1.37 & 0.23 & 2.99 \\
\hline & SI200 & 0.20 & 0.33 & 0.07 & 0.10 & 0.04 & 0.74 \\
\hline & $\mathrm{F} 1$ & 0.71 & 0.36 & 0.10 & 1.71 & 0.30 & 3.18 \\
\hline & $\mathrm{F} 2$ & 0.81 & 0.72 & 0.11 & 0.65 & 0.24 & 2.53 \\
\hline & $\mathrm{F} 3$ & 1.02 & 0.56 & 0.10 & 2.56 & 0.32 & 4.56 \\
\hline & K & 0.58 & 0.38 & 0.11 & 0.30 & 0.07 & 1.44 \\
\hline & Mean value & 0.66 & 0.47 & 0.10 & 1.06 & 0.19 & 2.48 \\
\hline
\end{tabular}

Samples: K denotes crater on the pit F1; F1, F2, and F3 denote pits; SI200 denotes sample collected in the north-east direction, $200 \mathrm{~m}$ from the center of the pit F1

${ }^{\mathrm{a}}$ The individual contamination factor (ICF) and global contamination factor (GCF) classifications: ICF $<0 \& \mathrm{GCF}<6$ - indicates low, $1<\mathrm{ICF}<3 \& 6<\mathrm{GCF}<12$ moderate, $3<\mathrm{ICF}<6 \& 12<$ GCF $<24$ considerable, and ICF $>6 \&$ GCF $>24$ high contamination (Zhao et al. (2012)

In all tested samples, the lowest ICF values were recorded for $\mathrm{Ni}$ and were fairly uniform regardless of the position taken from the soil sample. $\mathrm{Pb}$ and $\mathrm{Zn}$ also had approximately uniform contamination factors in all three layers of soil (Table 7). Due to very low ICF values for $\mathrm{Pb}, \mathrm{Ni}$, and $\mathrm{Zn}$, it could be concluded that their retention time and mobility potential are very small $(<1)$.

GCF is important because it provides a comprehensive potential risk for heavy metals (Ikem et al. 2003). The highest GCF value was found at F3 position, while the lowest in the SI200 position, independent of the depth. In general, looking at the average values, it could be said that the GCF decreased with depth.

The results in Table 7 indicate that ICF show low risk (in individual positions because it is below 1) to moderate risk (in individual positions because it ranges from
1 to 3 ) for $\mathrm{Cu}$ and $\mathrm{Cd}$, while for other metals, it shows low risk in terms of retention time and potential mobility in the examined area. GCF shows low risk for all analyzed metals.

In the literature, different values of ICF and GCF for metals in the soil can be found. Thus, in agricultural soil near the farm, for most heavy metals, a low risk was established from the aspect of their retention, except for $\mathrm{Cd}$ that showed a high risk for the examined area (Matong et al. 2016). In contrast, in soil samples from a location around the phosphate fertilizer industry, the average ICF values for metals have followed the lines: $\mathrm{Pb}>\mathrm{Zn}>\mathrm{Mn}>\mathrm{Co}>\mathrm{Cu}>\mathrm{Cr}>\mathrm{Ni}>\mathrm{Fe}$. A highest risk of zinc and lead contaminations was found at two individual positions, with ICF values of 4.78 and 3.91, respectively, while for other metals, significantly lower values were established. The highest GCF was found in surface soil samples, and it is decreased with depth (Wali et al. 2014). Results of the average GCF values in soil samples at polygon of Glamoc (slight decrease in the GCF values with sample depth) are in line with the conclusions of Wali et al. (2014) that metals are accumulating in surface layers of soil. Yao et al. (2006) examined the contamination factors for the six elements in the sediment of Dongting Lake in Central China, where the following lines were found: $\mathrm{Cd}>\mathrm{Pb}>\mathrm{Zn}>$ $\mathrm{Cu}>\mathrm{Ni}>\mathrm{Cr}$. The remobilization of metals is influenced by many factors such as chemical speciation, the physico-chemical characters, and $\mathrm{pH}$ of the water body (Ikem et al. 2003; Yao et al. 2006). The mechanism of migration and transformation of heavy metals can be summarized as ion exchange, dissolution, and desorption (Duddridge and Wainwright 1981; Lin and Chen 1998). Among the numerous influencing factors, $\mathrm{pH}$ is one of the main factors (Inmaculada et al. 2004). Appel and $\mathrm{Ma} 2002$, found that $\mathrm{pH}$ is the main factor affecting the adsorption characteristics of heavy metals, which controls the solubility of hydroxides, carbonates, and phosphates of heavy metals, and also affects the hydrolysis of heavy metals in sediments and organic matter, dissolved clay surface charge changes, and the formation of ion pairs. The risk of the presence of metals could be affected by redox conditions in the soil. Metals which are bound to Fe-Mn oxides are especially sensitive to redox conditions. Thus, under reduction conditions, the release of metals that are present in the $\mathrm{Fe}-\mathrm{Mn}$ oxide phase can occur due to their dissolution. Because the analyzed metals in individual positions in the polygon of Glamoc are present in the Fe-Mn oxide fraction, the 
change in redox conditions can lead to an increase in the risk of pollution.

Since GCF values are not comparable to any standards, the effect of a combination of metals on soil contamination cannot be thoroughly examined.

\section{Conclusion}

Intensive use of soil for military purposes directly affects the physical and chemical characteristics of the soil, and in the most cases, it leads to its irreversible degradation.

Destruction of ammunition, mines, and explosive devices by open detonation represents the ecologically least favorable option for resolving surplus of ammunition and mine explosive devices. Since there is no pollution control, the areas used for these purposes become contaminated with dangerous and/or toxic substances. At these locations, elevated concentrations of heavy metals are often detected.

About $30 \%$ of the surpluses within the Armed Forces of Bosnia and Herzegovina are destroyed by the method of open detonation at the Glamoc polygon. There are no technical measures to prevent contamination. This condition inevitably could lead to contamination of the polygon by heavy metals. The favorable circumstance is that the soil of the examined area corresponds to a silty-loamy structure and shows an alkaline reaction of the soil.

A research that was carried out at the polygon of Glamoc showed that the metals $\mathrm{Cd}, \mathrm{Ni}, \mathrm{Cu}$, and $\mathrm{Zn}$ were present above the maximum allowable concentration, while $\mathrm{Pb}$ was within the maximum allowed limits. The results of the applied sequential extraction show that $\mathrm{Cd}$ and $\mathrm{Zn}$ are predominantly present in the residual and oxide fractions, while $\mathrm{Pb}$ and $\mathrm{Ni}$ are predominantly present in the residual, then the oxide, and the organic fraction. $\mathrm{Cu}$ in addition to the residual, organic, and oxide phase is also significantly present in the carbonate fraction in the area of pits and crater. $\mathrm{Cd}$ is also significantly presented in mobile fractions, which speaks of anthropogenic effect. $\mathrm{Pb}, \mathrm{Ni}$, and $\mathrm{Zn}$ are present in very small quantities in mobile and easily available fractions, which suggests a lower risk of these elements in the environment. The determination of the risk assessment code (RAC) and the ICF and GCF values was also used to evaluate the potential mobility and bioavailability of the analyzed metals. According to the risk assessment,
Cd belongs to the most problematic metal from the aspect of mobility and accessibility for the examined area because the identified risk ranged from low to high, depending on the sample tested. $\mathrm{Cu}, \mathrm{Pb}$, and $\mathrm{Zn}$ show low risk, while Ni shows no risk to the environment in the area when looking at the aspect of mobility and accessibility for the flora and fauna. ICF shows low risk for all analyzed metals except for some $\mathrm{Cu}$ and $\mathrm{Cd}$ positions where moderate risk is present in terms of retention time and potential mobility in the examined area. The results indicated that soil at the polygon of Glamoc was low $(\mathrm{GCF}<6)$ impacted by heavy metals. However, continued anthropogenic activities in this region may cause the heightened degree of contamination, which could result in considerable risks to the local population and the local floras and faunas.

\section{References}

Abdu, N. (2010). Availability, transfer and balances of heavy metals in urban agriculture of West Africa. Kassel, Germany: Kassel University Press GmbH.

Adriano, D. C. (2001). Trace elements in terrestrial environments: biogeochemistry, bioavailability and risks of metals, Springer-Verlag (second ed.880 pp). New York.

Aiju, L., Yanchun, G., Honghai, W., \& Gao Peiling, G. (2012). An assessment of heavy metals contamination in Xiaofu River sediments through chemical speciation study. International Journal of Earth Sciences, 5(5), 1235-1240.

Alverbro, K., Björklund, A., Finnveden, G., Hochschorner, E., \& Hägvall, J. (2009). A life cycle assessment of destruction of ammunition. Journal of Hazardous Materials, 170, 11011109.

Ampleman, G., Thiboutot, S., Diaz, E., Brochu, S., Martel, R., \& Walsh, M. (2013). New range design and mitigation methods for sustainable training. Finnish Ministry of Defence: European Conference of Defence and the Environment.

Appel, C., \& Ma, L. (2002). Concentration, pH, and surface charge effects on cadmium and lead sorption in three tropical soils. Journal of Environmental Quality, 31, 581-589.

Banerjee, A. D. K. (2003). Heavy metal levels and solid phase speciation in street dusts of Delhi, India. Environmental Pollution, 123, 95-105.

Barać, N. M. (2017). Mobilnost i biodostupnost odabranih elemenata u poljoprivrednom zemljištu aluviona reke Ibar, Doktorska disertacija, Univerzitet u Beogradu, Tehnološkometaluruški fakultet, (In Serbian).

Barona, A., Aranguiz, I., \& Elias, A. (1999). Assessment of metal extraction, distribution and contamination in surface soils by a 3-step sequential extraction procedure. Chemosphere, 39(11), 1911-1922. 
Belanović, S., Knežević, M., Kadović, R., \& Danilović, M. (2003). Distribucija nekih teških metala u zemljištima bukovih zajednica NP Đerdap. Glasnik Šumskog fakulteta, Beograd, 88, 17-25 (In Serbian).

Best Practice Guide on the Destruction of Conventional Ammunition (2008). Government of the Netherlands. ,FSC.DEL/59/08/Rev.1. https://www.osce.org/fsc/33407 ?download=true, Accessed 10 January 2018.

Bogdanović, D. (2002). Izvori zagađenja zemljišta kadmijumom. Review, Letopis naučnih radova, 1, 32-42 (In Serbian).

Bradl, H.B., Kim, C., Kramar, U., Stiiben, D. (2005). Interactions of heavy metals, Chapter 2, Heavy metal in the Environment, Elsevier. 28-164.

Canuto, F. A. B., Garcia, C. A. B., Alves, J. P. H., \& Passos, E. A. (2013). Mobility and ecological risk assessment of trace metals in polluted estuarine sediments using a sequential extraction scheme. Environmental Monitoring and Assessment, 185(7), 6173-6185.

Cerqueira, B., Vega, F. A., Serra, C., Silva, L.F.O., Andrade, M.L. (2011). Time of flight secondary ion mass spectrometry and high-resolution transmission electron microscopy/energy dispersive spectroscopy: a preliminary study of the distribution of $\mathrm{Cu}^{2+}$ and $\mathrm{Cu}^{2+} / \mathrm{Pb}^{2+}$ on a Bt horizon sufrace. Journal of Hazardous Materials, 195, 422-431.

Certini, G., Scalenghe, R., \& Woods, W. I. (2013). The impact of warfare on the soil environment. Earth-Science Reviews, $127,1-15$.

Christensen, T. H. (1984). Cadmium soil sorption at low concentration. I. Effect of time, cadmium load, $\mathrm{pH}$ and calcium. Water, Air, and Soil Pollution, 21, 105-114.

Cordos, E., Rautiu, R., Roman, C., Ponta, M., Frentiu, T., Sarkany, A., Fodorpataki, L., Macalik, K., McCormick, C., \& Weiss, D. (2003). Characterization of the rivers system in the mining and industrial area of Baia Mare, Romania. European Journal of Mineral Processing and Environmental Protection, 3, 324-335.

Dar, G. H. (1996). Effects of cadmium and sewage-sludge on soil microbial biomass and enzyme activities. Bioresource Technology, 56, 141-145.

Davutluoglu, O. I., Seckin, G., Ersu, C. B., Yilmaz, T., \& Sari, B. (2011). Heavy metal content and distribution in surface sediments of the Seyhan River, Turkey. Journal of Environmental Management, 92, 2250-2259.

de Passos, E. A., Alves, J. C., dos Santos, I. S., do Alves, J. P. H., Garcia, C. A. B., \& Spinola Costa, A. C. (2010). Assessment of trace metals contamination in estuarine sediments using a sequential extraction technique and principal component analysis. Microchemical Journal, 96(1), 50-57.

Dias da Silva, A. A., Brum, T., Barbosa, M. C., \& Soares Marques, M. E. (2014). Investigation of a military site for destruction of ammunitions by open detonation with emphasis on $\mathrm{Pb}$ and Cu contamination (pp. 1-8). Brasil: XVII Congreso Brasilero de Mecánica dos Solos e Engenharia Geotécnica.

Doelman, P., \& Haanstra, L. (1984). Short-term and long-term effects of cadmium, chromium, copper, nickel, lead and zinc on soil microbial respiration in relation to abiotic soil factors. Plant Soil, 79, 317-327.

Dostava informacija za poligon Glamoč, Hercegbosanske šume d.o.o. Kupres, broj: 01/ 1-1862/15 od 05.11.2015. (in Bosnian).
Duddridge, J. E., \& Wainwright, M. (1981). Heavy metals in river sediments - calculation of metal adsorption maxima using Langmuir and Freundlich isotherms. Environmental Pollution Series B, Chemical and Physical, 2, 387-397.

Durres (2012.). Stanje u oblasti naoružanja i municije u OS BiH, Ministarstvo odbrane BiH, (In Serbian).

Farrah, H., \& Pickering, W. F. (1977). The sorption of lead and cadmium species by clay minerals. Australian Journal of Chemistry, 30, 1417-1422.

Ghrefat, H., Jusuf, N., Jamarh, A., \& Nazzal, J. (2012). Fractionation and risk assessment of heavy metals in soil samples collected along Zerqa River. Jordan, Environmental Earth Sciences, 66(1), 199-208.

Greičiûté, K., Juozulynas, A., Šurkienè, G., \& Valeikienė, V. (2007). Research on soil disturbance and pollution with heavy metals in military grounds. Geologija, no, 57, 14-20.

Guillén, M. T., Delgado, J., Albanese, S., Nieto, J. M., Lima, A., \& De Vivo, B. (2012). Heavy metals fractionation and multivariate statistical techniques to evaluate the environmental risk in soils of Huelva Township (SW Iberian Peninsula). Journal of Geochemical Exploration, 119-120, 32-43.

Guo, P., Xie, Z., Li, J., Kang, C., \& Liu, J. (2005). Relationships between fractionations of $\mathrm{Pb}, \mathrm{Cd}, \mathrm{Cu}, \mathrm{Zn}$ and $\mathrm{Ni}$ and soil properties in urban soils of Changchun, China. Chinese Geographical Science, 15, 179-185.

Gworek, B., \& Mocek, A. (2003). Comparison of sequential extraction methods with reference to zinc fractions in contaminated soils. Polish Journal of Environmental Studies, 12(1), 41-48.

Hagfors, M. (2013). Destruction of old expired and spoiled munition in Finland - environmental effects of open surface mass detonations, Finnish Defence Forces Technical Research Centre, Explosives and NBC Defence Division, Explosives Technology, European Conference of Defence and the Environment, Finnish Ministry of Defence, 119-128.

Han, F. X., Banin, A., Kingery, W. L., Triplett, G. B., Zhou, L. X., Zheng, S. J., \& Ding, W. X. (2003). New approach to studies of heavy metal redistribution in soil. Advances in Environmental Research, 8, 113-120.

Hessling, J.L., Esposito, M.P., Traver, R.P., Snow, R.H. (1989). Results of bench-scale research efforts to wash contaminated soils at battery-recycling facilities. Metals Speciation, Separation, and Recovery. Patterson, J.W., Passino, R. (Eds.), Lewis Publishers, Chelsea, MI, 497-514.

Ikem, A., Egiebor, O. N., \& Nyavor, K. (2003). Trace elements in water, fish and sediment from Tuskegee Lake, southern USA. Water, Air, and Soil Pollution, 149, 51-75.

Inmaculada, R., Ángel, F. J. M., \& Abelardo, G. P. (2004). The influence of $\mathrm{pH}$ and salinity on the toxicity of heavy metals in sediment to the estuarine clam Ruditapes philippinarum. Environmental Toxicology and Chemistry, 23, 1100-1107.

ISO 10381-1:2002, Soil quality - Sampling - Part 1: Guidance on the design of sampling programmes.

ISO 10381-2:2002, Soil quality - Sampling - Part 2: Guidance on sampling technique.

Jain, C. K. (2004). Metal fractionation study on bed sediments of River Yamuna. India, Water Research, 38, 569-578.

Jamali, M. K., Kazi, T. G., Afridi, H. I., Arain, M. B., Jalbani, N., \& Memon, A. R. (2007). Speciation of heavy metals in untreated domestic wastewater sludge by time saving BCR 
sequential extraction method. Journal of Environmental Science and Health, Part A, 42, 649-659.

Jena, V., Gupta, S., Dhundhel, R. S., Matic, N., Bilinski, S. F., \& Dević, N. (2013). Determination of total heavy metal by sequential extraction from soil. International Journal of Research in Environmental Science and Technology, 3(1), 35-38.

Jurinak, J. J., \& Bauer, N. (1956). Thermodynamics of zinc adsorption on calcite, dolomite and magnesite-type minerals. Soil Science Society of America Proceedings, 20, 466-471.

Kabata-Pendias, A. (2011). Trace elements in soils and plants. Fourth Edition. CRC Press, Taylor Francis Group, 6000 Broken Sound Parkway NW, Suite 300 Boca Raton, FL.

Kashem, M. A., Singh, B. R., \& Kawai, S. (2007). Mobility and distribution of cadmium, nickel and zinc in contaminated soil profiles from Bangladesh. Nutrient Cycling in Agroecosystems, 77, 187-198.

Kashem, M. A., Singh, B. R., Imamul Huq, S. M., \& Kawai, S. (2011). Fractionation and mobility of cadmium, lead and zinc in some contaminated and non-contaminated soils of Japan. Journal of Soil Science and Environmental Management, 3(9), 241-249.

Kastori, R. (1997). Teški metali u životnoj sredini, Naučni institut za ratarstvo i povrtarstvo, Novi Sad, (In Serbian).

Kierczak, J., Neel, C., Aleksander-Kwaterczak, U., Helios Rybicka, E., Bril, H., \& Puziewicz, J. (2008). Solid speciation and mobility of potentially toxic elements from natural and contaminated soils: A combined approach. Chemosphere, 73, 776-784.

Kubová, J., Matúš, P., Bujdoš, M., Hagarová, I., \& Medved, J. (2008). Utilization of optimized BCR three-step sequential and dilute $\mathrm{HCl}$ single extraction procedures for soil-plant metal transfer predictions in contaminated lands. Talanta, 75(4), 1110-1122.

Li, X., \& Thornton, I. (2001). Chemical partitioning of trace and major elements in soils contaminated by mining and smelting activities. Applied Geochemistry, 16, 1693-1706.

Li, P., Lin, C., Cheng, H., Duan, X., \& Lei, K. (2015). Contamination and health risks of soil heavy metals around a lead/zinc smelter in southwestern China. Ecotoxicology and Environmental Safety, 113, 391-399.

Lighthart, B., Baham, J., \& Volk, V. V. (1983). Microbial respiration and chemical speciation in metal-amended soils. Journal of.Environmental Quality, 12, 543-548.

Lin, J.-G., \& Chen, S.-Y. (1998). The relationship between adsorption of heavy metal and organic matter in river sediments. Environment International, 24, 345-352.

Lin, Z., Comet, B., Qvarfort, U., \& Herbert, R. (1995). The chemical and mineralogical behaviorof $\mathrm{Pb}$ in shooting range soils from Central Sweden. Environmental Pollution, 89, 303-309.

Linsday, W. L. (1972). Zinc in Soil and Plant Nutrition. Advances in Agronomy, 24, 147-186.

Lu, A., Zhang, S., \& Shan, X. (2004). Time effect on the fractionation of heavy metals in soils. Geoderma, 125(3-4), 225234.

Ma, L. Q., \& Rao, G. N. (1997). Chemical fractionation of cadmium, copper, nickel, and zinc in contaminated soils. Journal of Environmental Quality, 26, 259-264.

Malandrino, M., Abollino, O., Buoso, S., Giacomino, A., La Gioia, C., \& Mentasti, E. (2011). Accumulation of heavy metals from contaminated soil to plants and evaluation of soil remediation by vermiculite. Chemosphere, 82, 169-178.

Manninen, S., \& Tanskanen, N. (1993). Transfer of lead from shotgun pellets to humus and three plant species in a Finnish shooting range. Archives of Environmental Contamination and Toxicology, 24, 410-414.

Marković, J., Jović, M., Smičiklas, I., Pezo, L., Šljivić-Ivanović, M., Onjia, A., \& Popović, A. (2016). Chemical speciation of metals in unpolluted soils of different types: Correlation with soil characteristics and an ANN modelling approach. Journal of Geochemical Exploration, 165, 71-80.

Matong, J. M., Nyaba, L., \& Nomngongo, P. N. (2016). Fractionation of trace elements in agricultural soils using ultrasound assisted sequential extraction prior to inductively coupled plasmamass spectrometric determination. Chemosphere, 154, 249-257.

Mihelič, B. (2012). Energetske materije - eksplozivi, baruti i pirotehničke smješe, Bezbednost u radu sa ubojnim sredstvima, skladištenje, čuvanje i uništavanje ubojnih sredstava, Kragujevac, (In Serbian).

Moore, F., Nematollahi, M. J., \& Keshavarzi, B. (2015). Heavy metals fractionation insurface sediments of Gowatr bay-Iran. Environmental Monitoring and Assessment, 187(1), 1-14.

Naji, A., \& Ismail, A. R. (2011). Spatial variation and binding behavior of $\mathrm{Cu}$ and $\mathrm{Pb}$ in surface sediments of Klang River. International Journal of Chemical and Environmental Engineering, 2(2), 91-96.

Nannoni, F., Protano, G., \& Riccobono, F. (2011). Fractionation and geochemical mobility of heavy elements in soils of a mining area in northern Kosovo. Geoderma, 161(1-2), 6373.

Nemati, K., Bakar, N. K. A., Abas, M. R., \& Sobhanzadeh, E. (2011a). Speciation of heavy metals by modified BCR sequential extraction procedure in different depths of sediments from Sungai Buloh, Selangor, Malaysia. Journal of Hazardous Materials, 192(1), 402-410.

Nemati, K., Bakar, N. K. A., Abas, M. R., Sobhanzadeh, E., \& Low, K. H. (2011b). Comparison of unmodified and modified BCR sequential extraction schemes for the fractionation of heavy metals in shrimp aquaculture sludge from Selangor, Malaysia. Environmental Monitoring and Assessment, 176(1-4), 313-320.

Ogundiran, M. B., \& Osibanjo, O. (2009). Mobility and speciation of heavy metals in soils impacted by hazardous waste. Chemical Speciation \& Bioavailability, 21(2), 59-69.

Olajire, A. A., Ayodele, E. T., Oyedirdan, G. O., \& Oluyemi, E. A. (2003). Levels and speciation of heavy metals in soils of industrial southern Nigeria. Environmental Monitoring and Assessment, 85, 135-155.

Prasad, M. N. V. (2008). Trace elements as Contaminants and Nutrients: Cosequnces in Ecosystems and Human Health (p. 777). USA: John Wiley \& Sons.

Pravilnik FBiH 72/09. Pravilnik o utvrđivanju dozvoljenih količina štetnih i opasnih materija u zemljištu i metode njihovog ispitivanja, Službene novine FBiH broj 72/2009 (In Bosnian).

Quevauviller, P., Rauret, G., Muntau, H., Ure, A. M., Rubio, R., Lopez-Sanchez, J. F., Fiedler, H. D., \& Griepink, B. (1994). Evaluation of a sequential extraction procedure for the determination of extractable trace metal contents in sediments. Fresenius. Journal of Analytical Chemistry, 349, 808-814. 
Randhawa, N. S., \& Broadbent, F. E. (1965). Soil organic mattermetal complexes: 6 stability constants of zinc-humic acid complexes at different $\mathrm{pH}$ values. Soil Science, 99, 362-366.

Rauret, G., Lopez-Sanchez, J. F., Sahuquillo, A., Rubio, R., Davidson, C., Ure, A., \& Quevauviller, P. (1999). Improvement of the BCR three step sequential extraction procedure prior to the certification of new sediment and soil reference materials. Journal of Environmental Monitoring, 1, 57-61.

Reddy, K. J., Wan, L., \& Gloss, S. P. (1995). Solubility and mobility of copper, zink and lead in acidic enrichments. Plant and Soil, 171, 53-58.

Rule, J.H. (1998). Trace metal cation adsorption in soils: selective chemical extractions and biological availability. In: A. Dabrowski (ed) Adsorption and its applications industry and environmental protection, Vol. II: application in environmental protection. Studies in surface science and catalysis. Elsevier, 319-349.

SALW (2004). Ammunitions destruction - environmental releases from open burning (OB) and open detonation (OD) events, SEESAC. http://www.seesac.org/f/tmp/files/publication/304. pdf, Accessed 20. June 2017.

Sanders, J. R., \& Adams, T. M. M. (1987). The effects of pH and soil type on concentrations of zinc, copper and nickel extracted by calcium chloride from sewage sludge-treated soils. Environmental Pollution, 43, 219-228.

Sarkar, S.K., Favas, P.J.C., Rakshit, D., Satpathy, K.K. (2014). Geochemical speciation and risk assessment of heavy metals in soils and sediments, in: Hernandez-Soriano, M.C. (Ed.), Environmental Risk Assessment of Soil Contamination. In Tech, p. 918.

Shiowatana, J., Mclaren, R. G., Chanmekha, N., \& Samphao, A. (2001). Fractionation of arsenic in soil by a continuous-flow sequential extraction method. Journal of Environmental Quality, 30, 1940-1949.

Shuman, L. M. (1975). The effect of soil properties on zinc adsorption by soils. Soil Science Society of America Proceedings, 39, 454-458.

Smičiklas, I., Jović, M., Šljivić-Ivanović, M., Mrvić, V., Čakmak, D., \& Dimović, S. (2015). Correlation of $\mathrm{Sr}^{2+}$ retention and distribution with properties of different soil types. Geoderma, 253-254, 21-29.

Sungur, A., Soylak, M., Yilmaz, S., \& Ozcan, H. (2014). Determination of heavy metals in sediments of the Ergene River by BCR sequential extraction method. Environmental Earth Sciences, 72(9), 3293-3305.

Tessier, A., Campbell, P. G. C., \& Blsson, M. (1979). Sequential extraction procedure for the speciation of particulate trace metals. Analitical Chemistry, 51, 844-851.

Thiboutot, S., Ampleman, G., Brochu, S., Diaz, E., Martel, R., Hawari, J., Sunahara, G., Walsh, M. R., Walsh, M. E., \& Jenkins, T. F. (2012). Environmental characterization of military training ranges for munitions - related contaminants: Understanding and minimizing the environmental impacts of live - fire training. International Journal of Energetic Materials and Chemical Propulsion, 11(Issue 1), 17-57.
Thiboutot, S., Ampleman, G., Brochu, S., Diaz, E., Martel, R., Hawari, J., Sunahara, G., Walsh, M.R. and Walsh, M.E. (2013). Canadian Programme on the environmental impacts of munition, European Conference of Defence and the Environment, Finnish Ministry of Defence.

Thomas, E. Y. (2015). Assessment of heavy metal concentration and fractionation in selected dumpsite soils within Ibadan Metropolis, Nigeria. Journal of Agriculture and Ecology Research International, 4(3), 117-127.

Ure, A., Quevauviller, P., Munteau, H., Griepink, B. (1993). Improvements in the determination of extractable contents of trace metals in soils and sediments prior to certification. Tech. Rep., Community Bureau of reference, Commission of the European Communities.

Vega, F. A., Andrade, M. L., \& Covelo, E. F. (2010). Influence of soil properties on the sorption and retention of cadmium, copper and lead, separatly and together, by 20 soil horizons: comparasion of linear regression and tree regression analyses. Journal of Hazardous Materials, 174, 522-533.

Vig, K., Megharaj, M., Sethunathan, N., \& Naidu, R. (2003). Bioavailability and toxicity of cadmium to microorganisms and their activities in soil: a review. Advances in Environmental Research, 8, 121-135.

Wali, A., Colinet, G., \& Ksibi, M. (2014). Speciation of heavy metals by modified BCR sequential extraction in soils contaminated by phosphogypsum in Sfax, Tunisia. Environmental Research, Engineering and Management, 4(70), 14-26.

Yang, Z., Chen, F., Zhang, L., Liua, J., Wu, S., \& Kang, M. (2012). Comprehensive assessment of heavy metal contamination in sediment of the Pearl River Estuary and adjacent shelf. Marine Pollution Bulletin, 64, 1747-1955.

Yao, Z. G., Bao, Z. Y., Gao, P., Zhang, J. L., Guo, Y. P., Hu, Z. J., \& Li, B. L. (2006). Speciation of trace elements in sediments from Dongting Lake, Central China, Water Pollution VIII: Modelling, Monitoring and Management. WIT Transaction on Ekology an the Environment, 95, 119-128.

Zauyah, S., Juliana, B., Noorhafizah, R., Fauziah, C.I., Rosenani, A.B. (2004). Concentration and speciation of heavy metals in some cultivated and uncultivated ultisols and inceptisols in Peninsular Malaysia. Super Soil, 3rd Australian New Zealand Soils Conference., 1-5.

Zeien, H. (1995). Chemische Extraktionen zur Bestimmung der Bindungsformen von Schwermetallen in Böden (Chemical extractions to identify heavy metal binding forms in soils). Bonner Bodenkundliche Abhandlungen, 17, 284 pp.

Zhao, S., Feng, C., Yang, Y., Niu, J., \& Shen, Z. (2012). Risk assessment of sedimentary metals in the Yangtze Estuary: new evidence of the relationships between twotypical index methods. Journal of Hazardous Materials, 241-242, 164 172.

Zhu, H., Yuan, X., Zeng, G., Jiang, M., Liang, J., Zhang, C., Yin, J., Huang, H., Liu, Z., \& Jiang, H. (2012). Ecological risk assessment of heavy metals in sediments of Xiawan Port based on modified potential ecological risk index. Transactions of Nonferrous Metals Society of China, 22(6), 1470-1477. 